\title{
THE PERALKALIC MAGMATISM IN THE PRECAMBRIAN CACHOEIRINHA-SALGUEIRO FOLDBELT, NORTHEAST BRAZIL: GEOCHEMICAL ASPECTS
}

\author{
VALDEREZ P. FERREIRA* e ALCIDES N. SIAL**
}

\begin{abstract}
Peralkalic rocks of probable Brasiliano age intruded metasediments of the Precambrian Cachoeirinha and Salgueiro Groups and their basement, between the geographic coordinates $37^{\circ} \mathrm{W}$ and $40^{\circ} \mathrm{W}$ longitude and $7^{\circ} \mathrm{S}$ and $8^{\circ} 15^{\prime} \mathrm{S}$ latitude, Pernambuco and Paraiba states. They enclose two groups of aegirine and/or riebeckite-arfvedsonite-bearing rocks: (i) silica-saturated quartz-alkali-feldspar grayish-green trachytes and alkali-feldspar syenite, and (ii) silica-oversaturated quartz-alkali-feldspar syenite to alkali-feldspar granite (fluorite and cassiterite-bearing). The first group forms a dike swarm at Manaíra, Paraíba, and Terra Nova, Pernambuco, batholiths and dikes adjacent to the southern border of the Cachoeirinha-Salgueiro foldbelt, constituting a syenitoid line, besides small stocks piercing Cachoeirinha metasediments and the second one, dike swarms stocks and ring-dikes. The first group is characterized by normative nepheline and $\mathrm{K}_{2} \mathrm{O}$ (from 9.7 to $12.8 \%$ ) greater than $\mathrm{Na}_{2} \mathrm{O}$. Agpaitic index varies from 1.156 to 1.280 and in the second group ranges from 0.840 to 1.339 . The LREE are usually low and patterns for the two groups are very fractionated, LREE-enriched, HREE-deplete and Eu anomaly is rather missing. A very discrete negative Eu anomaly is seen in some of the saturated rocks, while the oversatured rocks exhibit, sometimes, a discrete positive Eu anomaly. Whole $\delta^{18} \mathrm{O}$ values are usually below 10 permilsMOW, except for the oversaturated subvolcanic dikes which intruded Cachoeirinha metasediments. Intense, early pyroxene fractionation from an alkali basic parental magma has been perhaps responsible for the generation of the Triunfo-syenite batholith, Pernambuco, and other syenites in the peralkalic syenitoid line. The peralkalinity of the Macacos hill oversaturated ring 'dike next to Serrita, Pernambuco, may have resulted from Bowen's plagioclase effect in the crystalization of a magma with trondhjemitic affinity.
\end{abstract}

\begin{abstract}
RESUMO Rochas peralcalinas de provável idade brasiliana intrudem metassedimentos précambrianos dos grupos Cachoeirinha e Salgueiro e seu embasamento, entre as coordenadas geográficas $37^{\circ}$ e $40^{\circ}$ de longitude W e $7^{\circ}$ e $8^{\circ} 15^{\prime}$ de latitude $S$, nos Estados de Pernambuco e Paraíba. Englobam dois grupos de rochas: saturadas em sflica (álcali-feldspato sienitos) e supersaturadas em silica (quartzo-álcali-feldspato sienitos a álcali-feldspato granitos, com fluorita e cassiterita). Esses corpos formam batólitos, stocks, enxames de diques e diques anelares, que cortam os metassedimentos Cachoeirinha, ou são adjacentes ao bordo sudeste do cinturão de dobramentos Cachoeirinha-Salgueito, constituindo um "cordão de sienitóides". O primeiro grupo é caracterizado por nefelina normativa e $\mathrm{K}_{2} \mathrm{O}$ (de $9,7 \%$ a $12,8 \%$ ) maior que $\mathrm{Na}_{2} \mathrm{O}$. $\mathrm{O}$ índice agpaítico varia de 1,156 a 1,280 e no segundo grupo varia de 0,840 a 1,339 . Os $\Sigma$ REE são normalmente baixos e anomalia de Eu está quase ausente. Valores $\delta 180$ em rocha total são normalmente menores que 10 permilsMow, exceto para alguns diques supersaturados, subvulcânicos, que intrudem os metasseđimentos Cachoeirinha. Intenso fracionamento inicial de piroxênio de um magma progenitor básico alcalino talvez tenha sido responsável pela geração do batólito sienítico de Triunfo, e outros sienitos do cordão de sienitóides peralcalinos. A peralcalinidade dos diques anelares de Serrita, Pernambuco, talvez tenha resultado do "efeito plagioclásio" na cristalização de um magma com afinidades trondhjemíticas.
\end{abstract}

INTRODUCTION Only few occurrences of peralkalic rocks have been recorded in Northeast Brazil. Among them, it deserves references: a) Cabo granite, $25 \mathrm{~km}$ south of Recife, Pernambuco (Borba \& Sial 1979, Sial et al. 1980, Long et al. in press); $b$ ) dikes of Independência and Tauá, Ceará (Almeida et al. 1984); c) ring-complex structures at Taperuaba, Ceará (Haddab \& Leonardos 1980), and d) dike at Catingueira, Paraíba (Almeida et al. 1967).

In a pioneer work ou granitoids of Northeast Brazil, Almeida et al. (1967) identified four main types in the area where the Cachoeirinha and Salgueiro Groups metasediments crop out, to the west of Parafba and Pernambuco states: (i) granitoids of the Conceição-type (granodiorites, tonalites and porphyritic granites); (ii) granitoids of the Itaporanga-type (extremely porphyritic granodiorites, where microcline megacrystals up to $10 \mathrm{~cm}$ long are common); (iii) granitoids of the Itapetim-type (late-orogenic biotite-granites); and (iv) peralkalic granitoids of the Catingueira-type. A geochemical zoning of the granitoids within the Cachoeirinha-Salgueiro foldbelt (CSF) was later verified by Sial (1984a, 1984b) through REF and stable-isotope studies. The peralkalic bodies of the Catingueira-type seem to represent the latest magmatic activity of the Brasiliano cycle in this region.

Barbosa (1970) mapped the major granitoids in the geographic space occupied by the metasediments of the Salgueiro and Cachoeirinha Groups (Piancó-Alto Brígida foldbelt of Brito Neves 1975), identifying granodiorites and alkali-syenites, besides a dike swarm of peralkalic affinities within the Salgueiro batholith. This was the first time that alkalic plutons were recorded in the western portion of the Cachoeirinha space. Santos (1971) recognized a syenitic body similar to he Catingueira-type of Almeida et al. (1967) next to Moderna, Pernambuco, not far from the Pernambuco lineament, and Vandoros \& Coutinho (1966) briefly described a body of this kind next to São Gonçalo, 
Paraiba. Sadowski (1973) studied the syenite batholith at Triunfo, Pernambuco, briefly commenting on its petrography and relationships with the syenite described at São Gonçalo.

Several graduation reports at the Department of Geology, Federal University of Pernambuco, have identified aegirine-bearing rocks in the area next to Terra Nova, southwest of Salgueiro, Pernambuco (e.g., Casé, Paulo, Duas Irmãs, and Livramento ridges; Maior 1980, Souza 1980, Sá 1982), next to Bernardo Vieira, Pernambuco (Batinga and Campo Grande hills; Moura 1982, Araújo Neto 1982), and next to Bom Nome, Pernambuco (Souza 1982). H.M.B. de Assis (oral communication) reported narrow riebeckite-bearing dikes next to Ouricuri, Pernambuco, crosscuting Cachoeirinha metasediments. Other peralkalic bodies have been recognized in this area and a detailed geological map is in preparation by the Department of Geology, Federal University of Pernambuco.

Sial (1984a, 1984b) found that the stocks near Serrita, Pernambuco, described by Caldasso (1967) are actually ring-complexes with core composed of rocks with trondhjemitc affinities, and ring-dikes of oversaturated peralkalic rocks.

Recently, the Companhia de Pesquisa de Recursos Minerais (CPRM) finished a geologic mapping (Silva Filho 1985 ) of the CSF. Although the main granitoids have been mapped, no special attention was given to the peralkalic bodies and the ring structures at Serrita have not been identified as so. This mapping, however, has been very useful in further identification of several peralkalic bodies or with peralkalic affinities in this area. Among them, the Cavalos and Quandu stocks, next to Sítio dos Moreiras, which pierced Cachoeirinha metasediments, and the Cana Brava stock, to the north of Carmo, Pernambuco, deserve citation.

An elongate batholith, mainly constituted of tonalite to granodiorite, is found at Solidão, Pernambuco, and has been mapped by Sial \& Menor (1969). This body which resembles somehow the Catingueira dike is one of the largest peralkalic bodies in this region, and has pierced metasediments of the Pajeú-Paraíba foldbelt.

At present, a detailed project aiming to study the petrography and geochemistry of the granitoids within the CSF is ongoing, financially supported by the PADCT program. In this paper, special attention will be devoted to the bodies of peralkalic affinities, found as batholith (Triunfo or Baixa Verde batholith, Pernambuco), dike swarms (Catingueira and Manaíra, Paraíba), ring-dikes at Serrita, and dikes at Santo Antonio Creek (Minador) to the north of Serrita, Pernambuco. These and other occurrences of peralkalic bodies found in the region under consideration are located in figure 1 and listed in table 1.

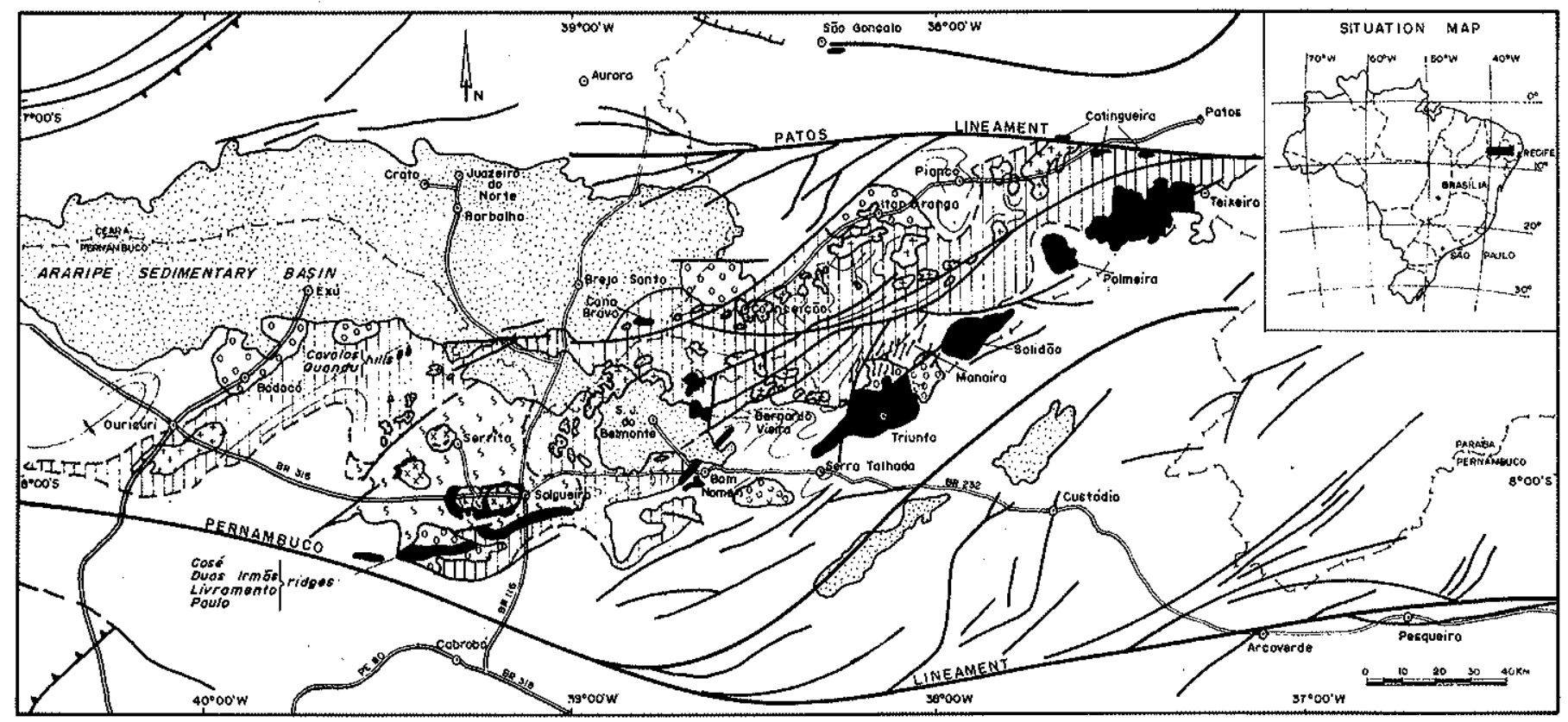

Rock Units
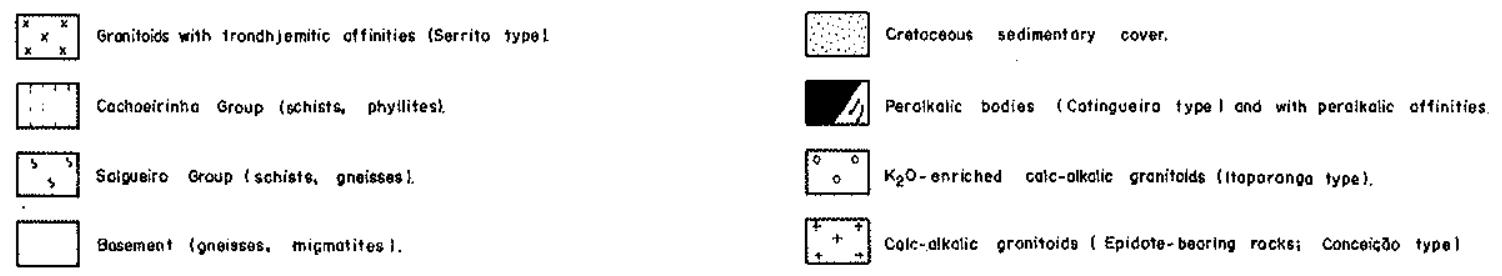

Figure 1 - Simplified geological map of the Piancó-Alto Brigida foldbelt, Northeast Brazil. Peralkalic rocks are shown in black (modified from Brito Neves 1983, Assunção 1983). The different groups of granitoids (potassic, calc-alkalic, peralkalic and of trondhiemitic affinity) are from Sial (1984a, 1984b) slightly modified 
Table 1 - Main occurences of peralkalic and with peralkalic affinities rocks in the Cachoeirinha-Salgueiro foldbelt, Northeast Brazil

\begin{tabular}{|c|c|c|c|c|c|}
\hline Locality & Form of intrusion & Wall-tocks & $\begin{array}{l}\text { Mineralogical } \\
\text { composition }\end{array}$ & Rock type & Reference \\
\hline \multicolumn{6}{|c|}{ OVERSATURATED ROCKS } \\
\hline $\begin{array}{l}\text { Serrita, Pernambuco } \\
\text { (Macacos, Vassouras } \\
\text { and Serrita hills) }\end{array}$ & $\begin{array}{l}\text { Ring-dikes in two stocks } \\
\text { of about } 70 \mathrm{~km}^{2} \text { each }\end{array}$ & $\begin{array}{l}\text { Salgueiro Group } \\
\text { metasediments }\end{array}$ & $\begin{array}{l}\text { Microcline, albite, } \\
\text { quartz, aegirine, } \\
\text { magnetite and } \pm \\
\text { cassiterite }\end{array}$ & $\begin{array}{l}\text { Quartz, alkali-feldspar } \\
\text { syenite }\end{array}$ & This work \\
\hline $\begin{array}{l}\text { Minador (Santo } \\
\text { Antonio Creek), } 30 \mathrm{~km} \\
\text { north of Serrita, } \\
\text { Pernambuco }\end{array}$ & $\begin{array}{l}\text { Narrow dikes, } 1 \mathrm{~km} \text { long } \\
\text { in average }\end{array}$ & $\begin{array}{l}\text { Cachoeirinha } \\
\text { Group } \\
\text { metasediments }\end{array}$ & $\begin{array}{l}\text { Microcline, quartz, } \\
\text { aegirine, riebeckite- } \\
\text { arfvedsonite, brown } \\
\text { amphibole, magnetite }\end{array}$ & $\begin{array}{l}\text { Quartz-alkali-feldspar } \\
\text { syenite }\end{array}$ & $\begin{array}{l}\text { Sial et al. } \\
1981 \mathrm{a}, 1981 \mathrm{~b}\end{array}$ \\
\hline $\begin{array}{l}\text { Catingueira, Campo } \\
\text { Grande and Urtiga } \\
\text { hills, Paraíba }\end{array}$ & $\begin{array}{l}\text { Dikes, hundreds of } \\
\text { meters wide up to } \\
12 \mathrm{~km} \text { long, trending } \\
\mathrm{E}-\mathrm{W}\end{array}$ & $\begin{array}{l}\text { Cachoeirinha } \\
\text { Group } \\
\text { metasediments }\end{array}$ & $\begin{array}{l}\text { Microcline, albite, } \\
\text { quartz, aegirine, ferro- } \\
\text { augite, magnetite } \pm \\
\text { fluorite }\end{array}$ & $\begin{array}{l}\text { Quartz-alkali-feldspar } \\
\text { syenite }\end{array}$ & $\begin{array}{l}\text { Almeida } \\
\text { et al. } 1967\end{array}$ \\
\hline Salgueiro, Pernambuco & $\begin{array}{l}\text { Margins of the Salgueiro } \\
\text { batholith }\end{array}$ & $\begin{array}{l}\text { Salgueiro Group } \\
\text { metasediments }\end{array}$ & $\begin{array}{l}\text { Microcline, ferro } \\
\text { augite, quartz, } \\
\text { magnetite } \pm \text { fluorite }\end{array}$ & $\begin{array}{l}\text { Quartz-alkali-feldspar } \\
\text { syenite }\end{array}$ & $\begin{array}{l}\text { Silva Filho } \\
1982, \text { Sial } \\
\text { et al. } 1982 \\
\end{array}$ \\
\hline Cana Brava hill, Carmo & Stock with about $12 \mathrm{~km}^{2}$ & $\begin{array}{l}\text { Cachoeirinha } \\
\text { Group } \\
\text { metasediments }\end{array}$ & $\begin{array}{l}\text { Microcline, } \\
\text { plagioclase, ferro } \\
\text { augite, bluish-green } \\
\text { amphibole }\end{array}$ & Granite & $\begin{array}{l}\text { Silva Filho } \\
1985\end{array}$ \\
\hline $\begin{array}{l}\text { Campo Alegre and } \\
\text { Batinga hills, Bernardo } \\
\text { Vieira, Pernambuco }\end{array}$ & $\begin{array}{l}\text { Two stocks with } 20 \text { and } \\
15 \mathrm{~km}^{2} \text {, respectively }\end{array}$ & $\begin{array}{l}\text { Cachoeirinha } \\
\text { Group } \\
\text { metasediments }\end{array}$ & $\begin{array}{l}\text { Microcline, } \\
\text { plagioclase, quartz, } \\
\text { bluish-green amphibole, } \\
\text { tbiotite, tfluorite }\end{array}$ & Quartz syenite & $\begin{array}{l}\text { Moura 1982, } \\
\text { Araújo Neto } \\
1982\end{array}$ \\
\hline $\begin{array}{l}\text { Barra da São Pedro, } \\
\text { Pau d'Arco, Ouricuri, } \\
\text { Pernambuco }\end{array}$ & $\begin{array}{l}\text { Narrow dikes, few meters } \\
\text { wide, trending } N-S\end{array}$ & $\begin{array}{l}\text { Cachoeirinha } \\
\text { Group } \\
\text { metasediments }\end{array}$ & $\begin{array}{l}\text { Microcline, aegirine, } \\
\text { quartz, riebeckite- } \\
\text { arfvedsonite, magnetite, } \\
\text { 土cassiterite }\end{array}$ & $\begin{array}{l}\text { Quartz-alkali-feldspar } \\
\text { syenite }\end{array}$ & $\begin{array}{l}\text { H.M.B. de } \\
\text { Assis (oral } \\
\text { communication) }\end{array}$ \\
\hline São Gonçalo, Paraíba & $\begin{array}{l}\text { Dike, } 12 \mathrm{~km} \text { long and } \\
500 \mathrm{~m} \text { wide, trending } \\
\mathrm{E}-\mathrm{W}\end{array}$ & $\begin{array}{l}\text { Uauá Group } \\
\text { gneiss }\end{array}$ & $\begin{array}{l}\text { Microcline, albite, } \\
\text { quartz, soda-augite, } \\
\text { richterite }\end{array}$ & $\begin{array}{l}\text { Quartz-alkali-feldspar } \\
\text { syenite }\end{array}$ & $\begin{array}{l}\text { Vandoros \& } \\
\text { Coutinho } \\
1966 \\
\end{array}$ \\
\hline $\begin{array}{l}\text { Teixeira and Palmeira, } \\
\text { Paraíba }\end{array}$ & $\begin{array}{l}\text { Batholith and stock, } \\
\text { respectively }\end{array}$ & $\begin{array}{l}\text { Archean (?) } \\
\text { gneiss-migmatite } \\
\text { complex }\end{array}$ & $\begin{array}{l}\text { Microcline, } \\
\text { placioclase, quartz, } \\
\text { bluish-green, amphibole, } \\
\pm \text { biotite }\end{array}$ & Granite & This work \\
\hline Solidão, Paraíba & $\begin{array}{l}\text { Batholith elongate } \\
\text { SW-NE }\end{array}$ & $\begin{array}{l}\text { Schits of the } \\
\text { Pajéu-Paraíba } \\
\text { foldbelt }\end{array}$ & $\begin{array}{l}\text { Plagioclase, microcline, } \\
\text { quartz bluish-green } \\
\text { amphibole }\end{array}$ & $\begin{array}{l}\text { Tonalite to } \\
\text { granodiorite }\end{array}$ & This work \\
\hline \multicolumn{6}{|c|}{ SATURATED ROCKS } \\
\hline Triunfo, Pernambuco & $\begin{array}{l}\text { Batholith occupying } \\
\text { about } 600 \mathrm{~km}^{2} \text {, slightly } \\
\text { elongate SW-NE }\end{array}$ & $\begin{array}{l}\text { Uauá, Salgueiro } \\
\text { Cachoeirinha } \\
\text { Groups }\end{array}$ & $\begin{array}{l}\text { Microcline, aegirine, } \\
\text { riebeckite- } \\
\text { arfvedsonite, } \\
\text { magnetite }\end{array}$ & $\begin{array}{l}\text { Alkali-feldspar } \\
\text { syenite }\end{array}$ & $\begin{array}{l}\text { Sadowski } \\
1973 ; \text { this } \\
\text { work }\end{array}$ \\
\hline $\begin{array}{l}\text { Paulo, Duas Irmãs, } \\
\text { Livramento and } \\
\text { Casé ridges, } \\
\text { south of Salgueiro, } \\
\text { Pernambuco } \\
\end{array}$ & $\begin{array}{l}\text { Dikes, up to } 25 \mathrm{~km} \\
\text { long }\end{array}$ & $\begin{array}{l}\text { Salgueiro and } \\
\text { Cachoeirinha } \\
\text { Groups } \\
\text { metasediments }\end{array}$ & $\begin{array}{l}\text { Microcline, aegirine, } \\
\text { quartz, albite, } \\
\text { magnetite }\end{array}$ & $\begin{array}{l}\text { Quartz-alkali-feldspar } \\
\text { syenite }\end{array}$ & $\begin{array}{l}\text { Sá } 1982, \\
\text { Major } 1980, \\
\text { Souza } 1980\end{array}$ \\
\hline $\begin{array}{l}\text { Terra Nova, } \\
\text { Pernambuco }\end{array}$ & $\begin{array}{l}\text { Dike swarm with } \\
\text { variable length and } \\
\text { width }\end{array}$ & $\begin{array}{l}\text { Cachoeirinha and } \\
\text { Salgueiro } \\
\text { metasediments }\end{array}$ & $\begin{array}{l}\text { Microcline, aegirine, } \\
\text { riebeckite- } \\
\text { arfvedsonite, tquartz, } \\
\text { magnetite }\end{array}$ & $\begin{array}{l}\text { Alkali-feldspar } \\
\text { syenite }\end{array}$ & This work \\
\hline $\begin{array}{l}\text { Salgueiro, } \\
\text { Pernambuco }\end{array}$ & $\begin{array}{l}\text { Dike swarm with } \\
\text { variable length and } \\
\text { width, in the N-S } \\
\text { direction } \\
\end{array}$ & $\begin{array}{l}\text { Granitic rocks of } \\
\text { the Salgueiro } \\
\text { batholith }\end{array}$ & $\begin{array}{l}\text { Microcline, aegirine, } \\
\text { quartz, riebeckite- } \\
\text { arfvedsonite, } \\
\text { magnetite }\end{array}$ & $\begin{array}{l}\text { Alkali-feldspar } \\
\text { syenite }\end{array}$ & Souza 1982 \\
\hline $\begin{array}{l}\text { Quandu and Cavalos } \\
\text { hills, Sítio dos } \\
\text { Moreiras, Pernambuco }\end{array}$ & $\begin{array}{l}\text { Two stocks with less } \\
\text { than } 10 \mathrm{~km}^{2} \text { each one }\end{array}$ & $\begin{array}{l}\text { Cachoeirinha } \\
\text { Group } \\
\text { metasediments }\end{array}$ & $\begin{array}{l}\text { Microcline, } \\
\text { plagioclase, ferro } \\
\text { augite, } \pm \text { riebeckite- } \\
\text { arfvedsonite, } \\
\pm \text { biotita }\end{array}$ & $\begin{array}{l}\text { Alkali-feldspar } \\
\text { syenite }\end{array}$ & This work \\
\hline $\begin{array}{l}\text { Manaíra, Princesa } \\
\text { Isabcl, Pernambuco }\end{array}$ & $\begin{array}{l}\text { Narrow dikes of } \\
\text { variable length, } \mathrm{N}-\mathrm{S} \\
\text { to SW-NE trend }\end{array}$ & $\begin{array}{l}\text { Cachoeirinha } \\
\text { Group } \\
\text { metasediemnts } \\
\text { and granodiorite } \\
\text { of the Itaporanga } \\
\text { lype }\end{array}$ & $\begin{array}{l}\text { Microcline, ortoclase, } \\
\text { albite, aegirine, } \\
\text { riebeckite- } \\
\text { arfvedsonite, } \\
\text { magnetite }\end{array}$ & $\begin{array}{l}\text { Alkali-feldspar } \\
\text { syenite to alkali } \\
\text { trachyte }\end{array}$ & Barbosa 1970 \\
\hline
\end{tabular}


GENERAL DESCRIPTIONS OF THE BODIES The peralkalic plutons under consideration are of variable size and among them the most voluminous one is the Triunfo batholith, Pernambuco, which occupies an area of 600 $\mathrm{km}^{2}$. This body is slightly elongate in the SW-NE direction and it exhibits fault or sharp contacts with biotite-schists of the Salgueiro Group, migmatites of the Uaua Group, and low-grade metamorphic rocks of the Cachoeirinha Group.

In the southernmost portion of the batholith, it assumes an arcuate structure, in topographic relief, which resembles a ring dike structure, with the core topographically in depression. The northern border of the batholith is in contact with a porphyritic granodiorite of the Itaporanga-type (Fig. 2). Xenoliths of the porphyritic granodiorite attest that the peralkalic igneous activity is younger than the potassic one, at this site.

Three large faults cut through the batholith, developing locally shear fabric. A primary lineation is given by sub-parallel arrangement of the pyroxene or K-feldspar grains,
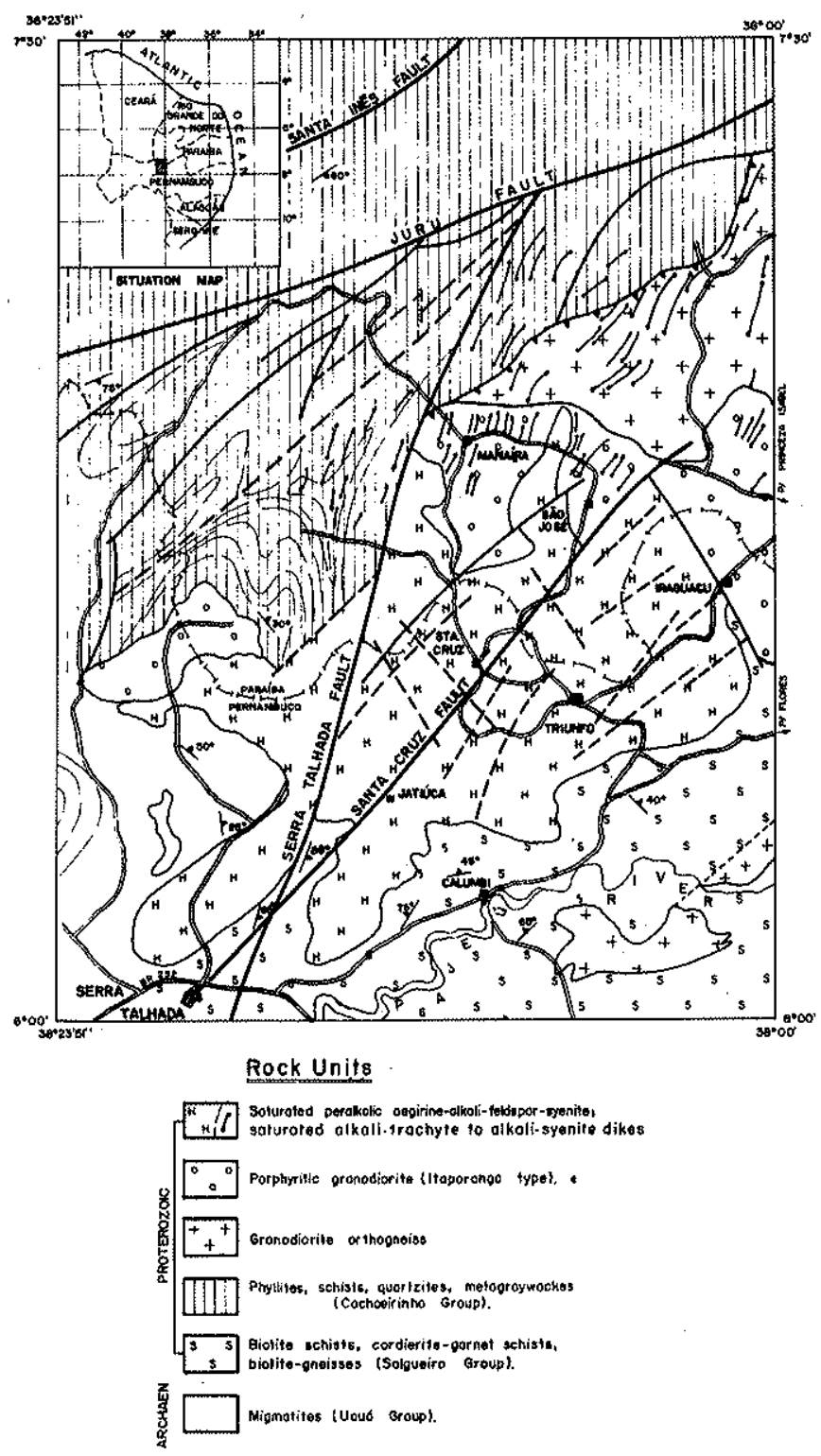

Figure 2 - Simplified geological map of the Triunfo area, Pernambuco (modified from the Silva Filho 1985) suggesting a syn- or late-tectonic emplacement. Numerous pyroxenite autoliths, aligned, are found throughout the Triunfo batholith. In some places they seem to be slightly folded, suggesting they reached a plastic state during the emplacement of the batholith. Locally, they are layered, with pyroxene and gray microcline cummulates, and some of them reacted with the residual liquid and generated a blue amphibole, often with a radial habit. Sulphides (pyrite and chalcopyrite? ) are present in some autoliths. Late, narrow pyroxenite dikes cut the batholith and have been partially disrupted by micro-faults or show boudinage and narrow dikes of syenitic composition were probably emplaced during a dilatation phenomenon as auto-intrusions.

Biotite-schists are seen as xenoliths of variable size, often showing reaction rims with the magma, which resulted in the crystallization of pyroxene around the xenolith. The batholith, in topographic relief, has been levelled at about $1,000 \mathrm{~m}$ high. As xenoliths of the wall rocks, although in small amount and size, are found throughout the batholith, it is assumed that this body was unroofed not very long ago.

Next to Serrita town, two round-stocks with trondhjemitic core have been eroded down to the ground level, while peralkalic ring-dikes next to the margins of the stocks are in topographic relief (Macacos, Vassouras, and Serrita hills, etc.). They are formed by a pink to gray quartz-alkali-feldspar syenite to alkali-feldspar granite, which locally shows layering, with an alternation of aegirine and $\mathrm{K}$-feldspar cummulates. These structures have been offset by micro-faults in en echelon fashion. A number of narrow dikes of uncertain relationships to the peralkalic rocks cut the stocks, usually normal to their margins. These ring-complexes are within the domain of the Salgueiro schists.

The Salgueiro batholith, Pernambuco, occupies an area of about $180 \mathrm{~km}^{2}$ and has been studied by Silva Filho (1982), Silva Filho et al. (1982) and Sial et al. (1983). Although ferroaugite has been identified and acmite is present in several norms, the partial peralkalic character of the batholith was not recognized. Usually, the ferroaugite-bearing rocks are found at the borders of the batholith, mainly in its eastern portion. Silva Filho's geological map coupled with field observations suggests that the batholith is formed by two adjacent ring-complexes (?), rocks with peralkalic affinities being usually in topographic relief. Rocks similar to the Serrita trondhjemitic, peraluminous, $\mathrm{Na}_{2} \mathrm{O}$-enriched rocks are found eroded down in the rest of the batholith.

About $30 \mathrm{~km}$ north of Serrita intruding the Cachoeirinha metasediments, there are few narrow dikes constituted by riebeckite-bearing quartz-enriched, with microcline phenocrysts, grayish-blue, very fine-grained rocks of subvolcanic emplacement (Santo Antônio Creek dikes).

Next to Catingueira, Paraiba, five dikes of peralkalic rocks have been recorded (Fig. 3). The longest one is the so-called Catingueira granite by Almeida et al. (1967) which intruded Cachoeirinha metasediments and developed a contact aureole in the hostschists with large staurolite crystals. Other dikes, topographic relief, are found at Campo Grande, Urtiga parallelling the Catingueira dike, the Patos lineament, and the Tigre fault. They have been sheared and stretching lineation is well developed. Deform. ed pegmatite veins are sometimes present. 


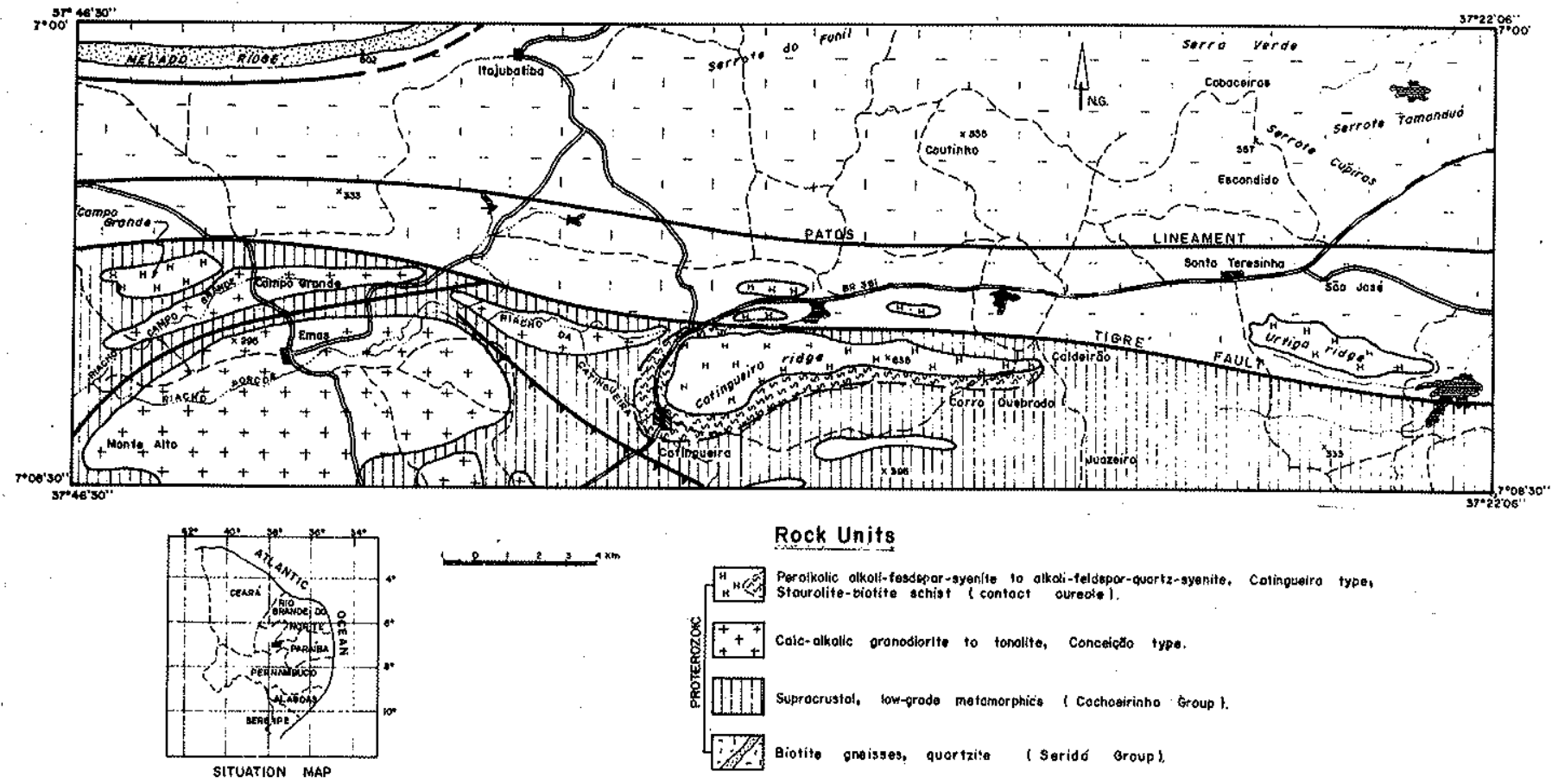

Figure 3 - Simplified geological map of the Caringueira area, Paraiba (modified from Silva Filho 1985)

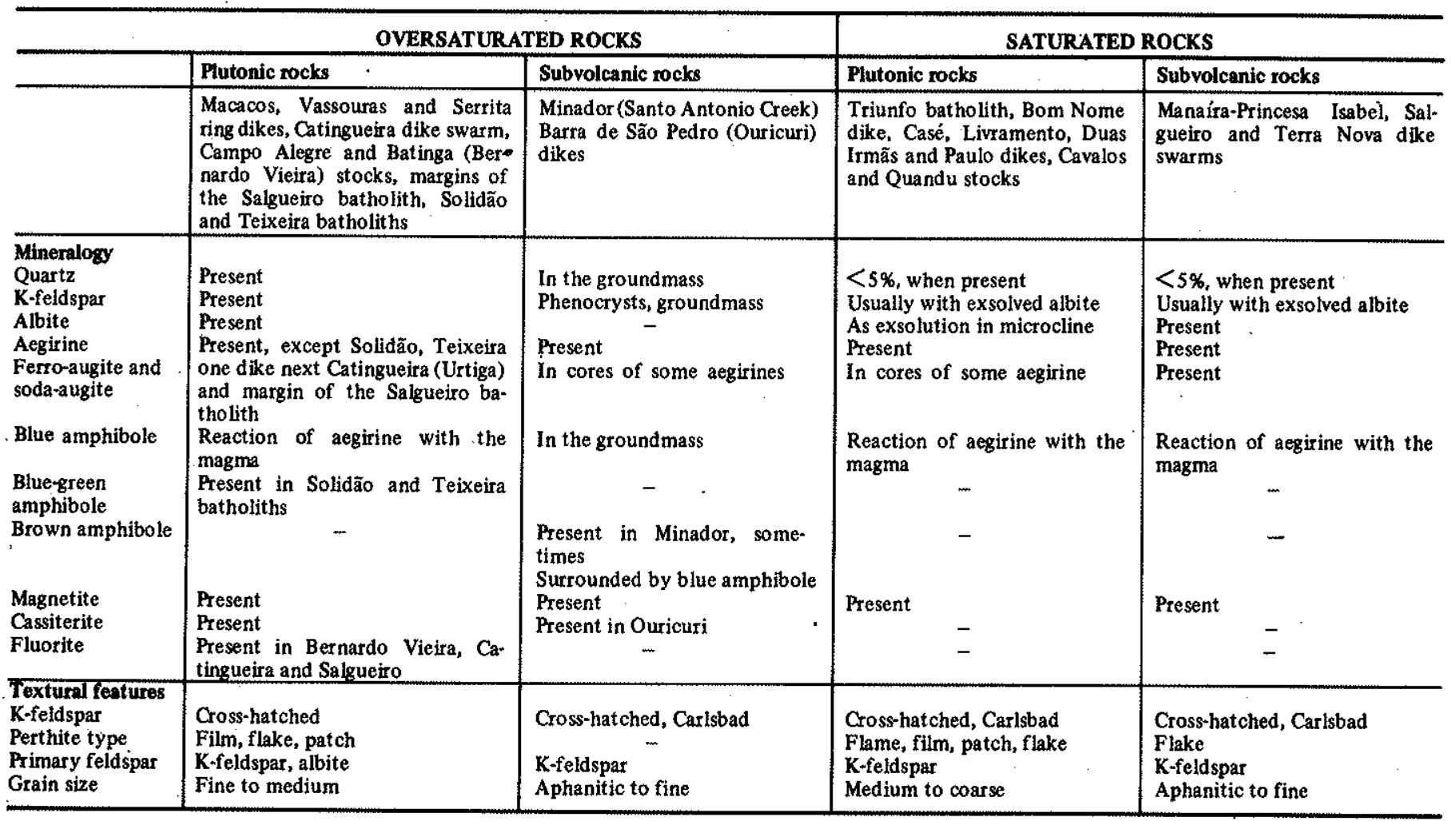


A well-developed dike swarm, trending SW-NE, is seen to the north of the Triunfo batholith, between Princesa Isabel and Manaíba, Paraíba, probably emplaced before the batholith, since no dike intrudes it.

Another dike swarm intruded the Salgueiro batholith, Pernambuco (Silva Filho 1982, Sial et al. 1983), and is characterized by narrow, long, N-S trending dikes, sometimes offset by micro-faults. These dikes are usually dark with syenitic composition. Similar dikes are also found to the south of this batholith, next to Terra Nova.

PETROGRAPHY A brief description of the petrography of the two groups of rocks is summarized in table 2.

Oversaturated rocks The ring-dikes in the ring-complexes (Macacos, Vassouras, and Serrita hills) and dikes next to Catingueira are predominantly composed of pink, gray to white alkali-feldspar syenite to minor alkali-feldspar granite. These rocks are made up of microcline, plagioclase, aegirine, quartz, sphene, apatite, and magnetite. Plagioclase is usually albite, oligoclase being only exceptionally seen (e.g., Catingueira dike) showing some alteration to calcite and epidote. Microcline, often in large subhedral grains, shows exsolved albite as film, flame, patch or flake perthite. Quartz occupies interstices and most of the time exhibits wavy extinction. Aegirine is the main pyroxene, showing a strong plechroism and subhedral crystals. In a few cases, ferroaugite cores are observed in these pyroxenes, which sometimes have margins partially transformed into a blue amphibole (riebeckite-arfvedsonite). Soda-augite is found in the Urtiga dike, not far from Catingueira. Early crystallized, slender crystals of apatite, and sphene are very common, usually included in microcline and aegirine. Subhedral magnetite crystals are found in the Catingueira dike, which seems to have crystallized under oxygen fugacity slightly high. Zoned, euhedral crystals of cassiterite, although not abundant, are seen at Macacos hill and interstitial fluorite, in the Catingueira dike.

The dikes next to Ouricuri, Pernambuco, show microcline phenocrysts including slender aegirine crystals, besides many elongate blue amphibole, aegirine, and small quartz, zoned cassiterite and euhedral magnetite crystals as accessory phases. In the groundmass, microcline and quartz show a striking preferred orientation.

The dikes which cut a stock of the Conceição-type about $30 \mathrm{~km}$ north of Serrita (Minador, Santo Antônio Creek) are composed of very fine-grained alkali-feldspar syenite, with microcline, quartz, a egirine, riebeckite-arfvedsonite, ferrohastingsite (?), and apatite. These rocks show a microporphyritic texture with an equigranular, microcrystalline, quartz-feldspar groundmass.

Large, euhedral microcline phenocrysts show sometimes the Carlsbad-type twinning, indicating it crystallized as orthoclase and inverted to microcline during the cooling. Some of them are mantled by albite and often show small, elongate crystals of aegirine, alkali-amphibole or apatite inclusions. In this rock, riebeckite-arfvedsonite is a primary phase, crystallized straight from the magma, abundant in the matrix, as very elongate prisms. Grains of euhedral ferrohastingsite (?), sometimes surrounded by riebeckite-arfvedsonite have been observed in few cases. Clinopyroxene, sometimes with ferroaugite core and aegirine

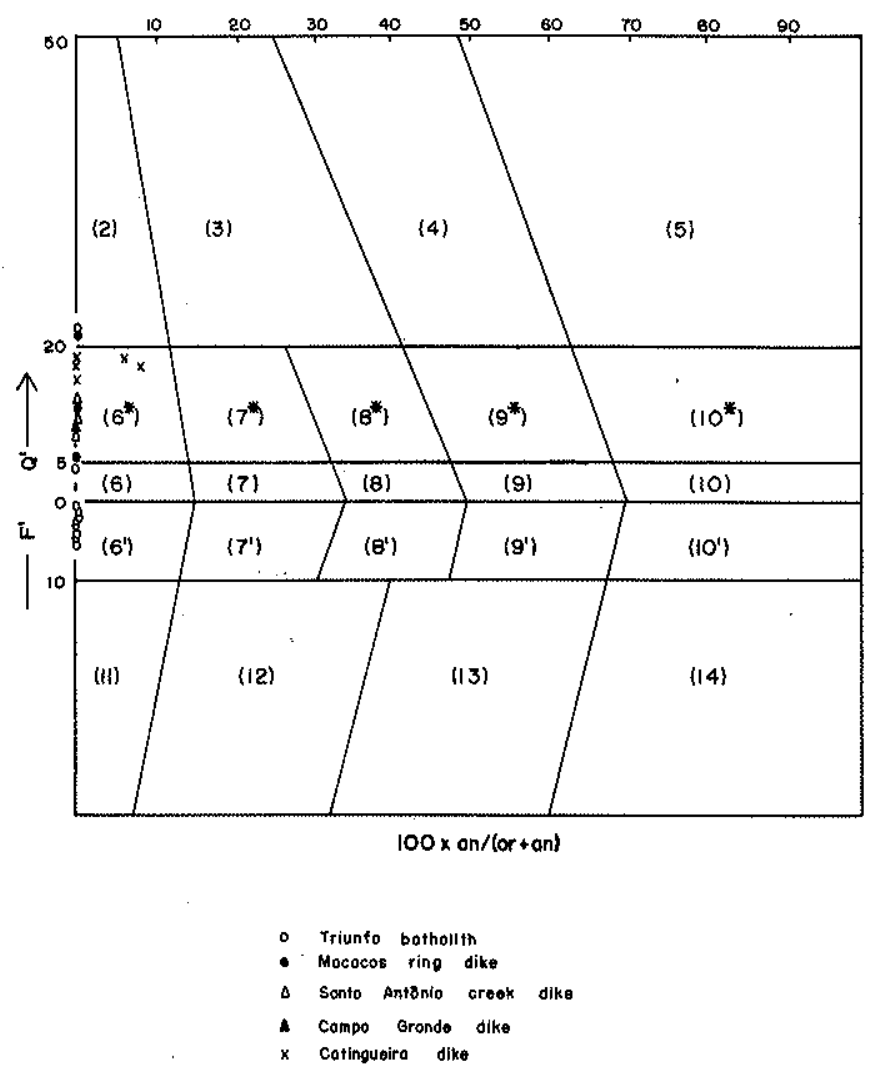

Figure 4-Chemical classification of peralkalic rocks in this study, according to Streckeisen \& LeMaitre (1979). Fields: 2 , alkali-feldspar granite; $6^{*}$, quartz-alkali-feldspar syenite; 6, alkali-feldspar syenite; and 6, alkali-feldspar syenite with feldspathoid

margins, is found in the groundmass as euhedral crystals. Apatite is a common accessory phase.

All samples studied lie in the quartz-alkali-feldspar syenite and alkali-feldspar granite fields of the Streckeisen's (1973) or Streckeisen \& LeMaitre (1979) classifications (Fig. 4).

Saturated rocks The Triunfo is the main body of this kind here studied. This body is remarkably homogeneous, composed of microcline (partially perthitic), aegirine, sphene, apatite, magnetite, and interstitial quartz. Pegmatite dikes are rare and only locally, narrow ones, up to $5 \mathrm{~cm}$ wide cut the batholith, with black amphibole and white microcline in comb-structures. Besides, finengrained dikes, up to $10 \mathrm{~cm}$ wide with identical composition to that of the batholith, crosscut it.

Euhedral to subheudral microcline has often exsolved albite, in flame, film, patch or flake patterns. In few cases, orthoclase cores have been recorded in some of these microcline crystals resulting from crystallization of a highly potassic liquid on cooling, were prevented from exsolution, not intersecting the albile-orthoclase solvus. Almost all $\mathrm{K}$-feldspar phenocrysts found in the Triunfo syenite are gray and probably formed in the pre-peralkalic stage of the evolution of the magma. This mineral occupies, in average, $79 \%$ of the volume of the rock.

Euhedral aegirine, sometimes zoned and twinned, is the main pyroxene, eventually with ferroaugite cores. Small, 
euhedral crystals of aegirine are found around biotite-rich xenoliths. This pyroxene has partially changed into a needle-like or fibrous blue amphibole, at its margins or along cleavages and fractures. Euhedral aegirine is often found included in microcline, and the opposite situation, although less common, is also observed. Aegirine occupies about $17 \%$ of the volume of the rock. Beside the blue amphibole a pale green one, weakly pleochroic, is locally observed (pargasite?). Amphiboles exhibiting a radial habit are seen in some slicken-side planes. Quartz is uncommon, occupying less than $5 \%$ of the total volume of the rock, restricted to the borders of the batholith. Usually, it is an interstitial phase, deformed, built up of independent plates, exhibiting flame-shadow patterns. Euhedral crystals of sphene and apatite are found within aegirine or feldspar grains. Only rarely iron oxide minerals are observed, usually as a secondary phase, resulting from transformation of aegirine to amphibole.

In some places, rocks next to the contact of the Triunfo batholith have been slightly fenitized as already recognized by Sadowski (1973)

The saturated rocks under discussion correspond to alkali-feldspar syenite in the Streckeisen's classification (1973) or alkali-feldspar syenite and alkali-feldspar syenite with feldspathoid according to Streckeisen \& LeMaitre (1979 in Fig. 4). The fenitized rock (TRF-6) corresponds to an alkali-feldspar granite.

The dike swarm between Princesa Isabel and Manaíra and the one next to Terra Nova are composed of a variety of rocks, which includes fine to intermediate grained, gray, white, green to pink rocks. The fine-grained types are composed of green to bluish alkalic rocks with orthoclase, microcline, albite, aegirine, ferroaugite, hedenbergite (?), blue amphibole, and apatite. Usually, they exhibit seriate to microporphyritic textures and have been emplaced as subvolcanic bodies. Some coarse-grained dikes, however, are mineralogically and texturally very similar to the body of Triunfo.

Microcline is by far the most abundant $\mathbf{K}$-feldspar, found as zoned, euhedral to subhedral crystals, showing Carlsbad and cross-hatched twinning, suggesting inversion from orthoclase. Only occasionally, flake perthite is observed. Very often small, needle-like crystals of apatite and aegirine are found included in microcline, preferentially next to the core of zoned crystals. Albite is also found included in microcline or surrounding deeply-weathered, sericitized $\mathrm{K}$-feldspar cores, or often as euhedral phenocrysts.

Pyroxene, represented by aegirine, ferroaugite, and hedenbergite (?), is sometimes deeply weathered, pseudomorphically replaced by amphibole or partially transformed into riebeckite-arfvedsonite. This amphibole appears as primary euhedral crystals in the groundmass, sometimes with radial habit, forming micro-porphyries. Twinned crystals are often seen.

The rocks are alkali-feldspar syenite to alkali-feldspar trachyte, according to Streckeisen's classification (1973).

GEOCHEMISTRY Twenty-nine samples - 10 of which from the Triunfo batholith (saturated group-SG) and 19 from the oversaturated group (OSG) - have been analysed in the Geosol Laboratory, Belo Horizonte, Minas Gerais, for major and trace elements. These chemical analyses and respective CIPW norms are listed in table 3.
Table 3 - Major and trace elements and CIPW norms of peralkalic rocks of the Cachoeirinha foldbelt, Northeast Brazil

\begin{tabular}{|c|c|c|c|c|c|c|c|c|c|c|}
\hline \multicolumn{11}{|c|}{ OVERSATURATED ROCKS } \\
\hline & $D C-1$ & $\mathrm{DC}-1 \mathrm{~A}$ & DC-3 & $\mathrm{DC}-4$ & DC. 5 & $\mathrm{DC}-6$ & CAT-1 & CAT.2 & CAT.5 & CAT 6 \\
\hline $\begin{array}{l}\mathrm{SiO}_{2} \\
\mathrm{TiO}\end{array}$ & $\begin{array}{r}69.70 \\
0.18\end{array}$ & $\begin{array}{r}70.30 \\
0.16\end{array}$ & $\begin{array}{r}71.50 \\
0.11\end{array}$ & $\begin{array}{r}70.20 \\
0.80\end{array}$ & $\begin{array}{r}66.10 \\
0.14\end{array}$ & $\begin{array}{r}71.50 \\
0.10\end{array}$ & 68.60 & 68.60 & 68.40 & 68.80 \\
\hline $\mathrm{Al}_{2} \mathrm{O}_{3}$ & 15.40 & 15.20 & $\begin{array}{l}.14 .80 \\
14.80\end{array}$ & 14.70 & $\begin{array}{l}0.14 \\
16.80\end{array}$ & $\begin{array}{l}0.10 \\
14.70\end{array}$ & $\begin{array}{r}0.21 \\
14.90\end{array}$ & $\begin{array}{r}0.22 \\
14.80\end{array}$ & $\begin{array}{r}0.21 \\
14.80\end{array}$ & $\begin{array}{r}0.22 \\
14.70\end{array}$ \\
\hline $\mathrm{Fe}_{2} \mathrm{O}_{3}$ & 0.24 & 0.32 & 0.40 & 0.87 & 1.20 & 0.82 & 1.10 & 2.10 & 1.20 & 0.75 \\
\hline $\mathrm{FeO}$ & 1.22 & 1.15 & 0.72 & 0.57 & 0.43 & 0.43 & 1.28 & 1.29 & 1.00 & 1.00 \\
\hline $\mathrm{MgO}$ & 0.33 & 0.30 & 0.10 & 0.25 & 0.17 & 0.08 & 0.43 & 0.43 & 0.43 & 0.48 \\
\hline $\mathrm{CaO}$ & 1.20 & 1.10 & 0.45 & 0.60 & 0.57 & 0.31 & 1.40 & 1.50 & $\$ 1.40$ & 1.40 \\
\hline $\mathrm{Na}_{2} \mathrm{O}$ & 5.60 & 5.70 & 5.80 & 6.10 & 6.40 & S.50 & 5.00 & 4.80 & 5.10 & 5.20 \\
\hline $\mathrm{K}_{2} \mathrm{O}$ & 4.30 & 4.20 & 5.00 & 5.20 & 6.20 & 5.50 & 6.40 & 6.30 & 6.60 & 6.70 \\
\hline $\mathrm{P}_{2} \mathrm{O}_{5}$ & 0.05 & 0.05 & 0.05 & 0.06 & 0.06 & $<0.05$ & 0.10 & 0.14 & 0,10 & 0.12 \\
\hline $\mathrm{CO}_{2+}$ & $<0.05$ & 0.09 & $<0.05$ & $<0.05$ & 0.22 & $<0.05$ & - & & & 0.12 \\
\hline $\mathrm{H}_{2} \mathrm{O}$ & 0.11 & 0.11 & 0.16 & 0.15 & 0.09 & 0.08 & 0.28 & 0.16 & 0.12 & 0.55 \\
\hline $\mathrm{H}_{2} \mathrm{O}^{\circ}$ & 0.02 & 0.20 & 0.23 & 0.02 & 0.27 & 0.09 & 0.18 & 0.15 & 0.06 & 0.06 \\
\hline Total & 98.40 & 98.88 & 99.37 & 98.87 & 98.65 & 99.21 & 99.88 & 100.47 & 99.42 & 99.98 \\
\hline Nb & $<20$ & $<20$ & $<20$ & $<20$ & $\frac{10}{30}$ & 24 & 10 & 21 & 18 & $\frac{719}{16}$ \\
\hline $\mathrm{Y}$ & $<10$ & $<10$ & $<10$ & $<10$ & 10 & 16 & 11 & 13 & 10 & 15 \\
\hline $\mathrm{Ba}$ & 7.850 & 7.350 & 3.200 & 5.200 & 3.900 & 3.600 & 5.210 & 4.450 & 4.570 & 4.870 \\
\hline $\mathrm{Zn}_{\mathrm{n}}$ & 59 & ss & 54 & 53 & 72 & 49 & 0.210 & 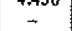 & - & - \\
\hline $\mathrm{Rb}$ & 43 & 42 & 140 & 99 & 140 & 140 & 150 & 180 & 150 & 145 \\
\hline Sz & 3.000 & 2.800 & 1.160 & 960 & 1.170 & $1.0 B O$ & 1.320 & 1.270 & 1.520 & 1.420 \\
\hline $\mathrm{Ga}$ & $<5$ & 12 & 9 & 11 & 12 & 14 & 1000 & - & - & \\
\hline$z_{z}$ & 82 & 76. & 140 & 90 & 306 & 220 & 70 & 140 & 130 & 150 \\
\hline a.j. & 0.900 & 0.916 & 1.010 & 1.065 & 1.026 & 1.020 & 1.020 & 0.990 & 1.050 & 1.07 \\
\hline D.1. & 90.13 & $91.2 \mathrm{I}$ & 95.70 & 92.80 & 94.26 & 95.84 & 91.46 & 92.68 & 90.03 & 90.48 \\
\hline$Q$ & 17.33 & 18.16 & 17.86 & $|5.4|$ & 15.72 & 18.35 & 12.63 & 14.20 & 11.64 & 12.57 \\
\hline or & 25.41 & 24.82 & 29.54 & 30.72 & 36.63 & 32.50 & 37.81 & 37.53 & 39.00 & 39.59 \\
\hline $\mathrm{Ab}$ & 47.39 & 48.23 & 48.30 & 46.67 & 51.91 & 45.00 & 41.02 & 40.95 & 39.39 & 38.32 \\
\hline An & 4.19 & 3.49 & 0.00 & 0.00 & 0.00 & 0.00 & 0.00 & 0.24 & 0.00 & 0.00 \\
\hline No & 0.00 & 0.00 & 0.00 & 0.00 & 0.00 & 0.00 & 0.00 & 0.00 & 0.00 & 0.00 \\
\hline Ac & 0.00 & 0.00 & 0.00 & 2.52 & 1.98 & 1.36 & 0.00 & 0.00 & 3.3 & 2.17 \\
\hline $\mathrm{Ns}_{\mathrm{s}}$ & 0.00 & 0.00 & 0.00 & 0.49 & 0.00 & 0.0 & 0.00 & 0.00 & 0.00 & 0.75 \\
\hline pi.Wo & 0.47 & 0.45 & 0.66 & 0.95 & 0.44 & 0.37 & 2.57 & 2.00 & 2.59 & 2.57 \\
\hline $\mathrm{Dj} \cdot \mathrm{En}$ & 0.16 & 0.15 & 0.14 & 0.3 & 0.30 & 0.14 & 1.01 & 1.03 & 1.07 & 1.12 \\
\hline DiFs & 0.33 & 0.31 & 0.57 & 0.56 & 0.10 & 0.24 & 1.53 & 0.92 & 1.5 & 1.45 \\
\hline $\mathrm{Hy} \cdot \mathrm{En}$ & 0.67 & 0.60 & 0.11 & 0.23 & 0.12 & 0.06 & 0.0 & 0.0 & 0.0 & 0.08 \\
\hline hy. Fs & 1.42 & 1.27 & 0.4 & 0.3 & 0.04 & 0.1 & 舟 & 0.00 & 0.0 & 0.10 \\
\hline Fo & 0.00 & 0.00 & 0.0 & 0. & & 0 & 0.00 & 0.00 & 0.00 & 0.00 \\
\hline $\mathrm{F}_{8}$ & 0.0 & 0.0 & 0. & & & 0.00 & n.00 & 0.00 & 0.00 & 0.00 \\
\hline wo & 0.00 & 0.00 & 0.00 & 0.00 & 0.00 & 0.00 & 0.00 & 0.00 & 0.0 & 0.00 \\
\hline $\mathrm{Mt}$ & 0.35 & 0.46 & 0.23 & 0.00 & 0.75 & 0.21 & 1.02 & 0.65 & 0.08 & 0.00 \\
\hline II & 0.34 & 0.30 & 0.2 & 0.1 & 0.27 & 0.19 & 0.40 & 1.61 & 0.40 & 0.42 \\
\hline $\mathrm{Hm}$ & 0.00 & 0.0 & 0.0 & 0.0 & 0.00 & 0.00 & 0.00 & 0.00 & 0.00 & 0.00 \\
\hline $\mathrm{AP}$ & 0.12 & 0.12 & 0.12 & 0.14 & 0.14 & 0.12 & 0.24 & 0.42 & 0.24 & 0.28 \\
\hline $\mathrm{Cc}$ & 0.11 & 0.20 & 0.11 & 0.13 & 0.50 & 0.11 & 0.00 & 0.00 & 0.00 & 0.00 \\
\hline
\end{tabular}

\begin{tabular}{|c|c|c|c|c|c|c|c|c|c|}
\hline & DCG-1 & $S M \cdot 1$ & SM.2 & SM-3 & SSA-1 & SSA.2 & SSA.3 & SER-63 & SER-44 \\
\hline $\mathrm{SiO}_{2}$ & 67.70 & 68.10 & 71.10 & 66.00 & 66.90 & 66.70 & 67.90 & 66.04 & 68.15 \\
\hline $\mathrm{TiO}_{2}$ & 0.15 & 0.25 & 0.30 & 0.31 & 0.16 & 0.12 & 0.18 & 0.45 & 0.36 \\
\hline $\mathrm{Al}_{2} \mathrm{O}_{3}$ & $\{5.00$ & 15.30 & 14.60 & 16.60 & 14.00 & 15.00 & 15.00 & $\{7.33$ & 14.60 \\
\hline $\mathrm{Ie}_{2} \mathrm{O}_{3}$ & 0.90 & 1.60 & 1.40 & 1.50 & 1.30 & 0.74 & 1.30 & 0.84 & 0.99 \\
\hline $\mathrm{FeO}$ & 0.72 & 0.57 & 0.64 & 0.57 & 0.86 & 0.86 & 0.86 & 0.86 & 1.08 \\
\hline $\mathrm{MgO}$ & 0.43 & 0.25 & 0.27 & 0.18 & 0.33 & 0.14 & 0.17 & $0.1 \mathrm{~s}$ & 0.31 \\
\hline $\mathrm{CaO}$ & 1.10 & 0.81 & 1.00 & 0.91 & 0.71 & 0.53 & 0.75 & [.61 & 1.40 \\
\hline $\mathrm{Na}_{2} \mathrm{O}$ & 5.30 & 5.70 & 6.20 & 6.40 & 6.40 & 6.40 & 4.20 & 6.33 & 4.85 \\
\hline $\mathrm{K}_{2} \mathrm{O}$ & 7. 10 & 5.80 & 3.40 & 5.80 & 7.60 & 8.10 & 8.60 & 3.85 & 6.93 \\
\hline $\mathrm{P}_{2} \mathrm{O}_{\mathrm{s}}$ & 0.10 & 0.07 & 0.07 & 0.08 & 0.11 & 0.05 & 0.14 & 0.52 & 0.24 \\
\hline $\mathrm{CO}_{2+}$ & $<0.05$ & 0.11 & $<0.05$ & $<0.05$ & 0.44 & 0.05 & 0.05 & 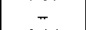 & - \\
\hline $\mathrm{H}_{2} \mathrm{O}$ & 0.18 & 0.17 & 0.15 & 0.16 & 0.14 & 0.13 & 0.14 & 0.04 & 0.10 \\
\hline $\mathrm{H}_{2} \mathrm{O}-$ & 0.20 & 0.34 & 0.20 & 0.00 & 0.13 & 0.12 & 0.13 & 1.08 & 0.48 \\
\hline Total & 98.93 & 99.08 & 99.38 & 98.56 & 99.08 & 98,94 & 99.42 & 98.77 & 99.49 \\
\hline $\mathrm{Nb}$ & 25 & 28 & 52 & 29 & 20 & 24 & $<20$ & - & - \\
\hline$\gamma$ & 10 & $<10$ & $<10$ & $<10$ & $<10$ & $<10$ & $<10$ & - & - \\
\hline $\mathrm{Ba}$ & 7.200 & 6.900 & 3.700 & 6.800 & 4.450 & 6.780 & 2.100 & - & .. \\
\hline $\mathrm{Zn}$ & 54 & 67 & 88 & 83 & 62 & 46 & 61 & - & - \\
\hline $\mathrm{Rb}$ & 100 & 78 & 75 & $7 !$ & 170 & 180 & 190 & - & - \\
\hline $\mathrm{Sr}$ & 1.270 & 760 & 1.660 & 1.820 & 430 & 470 & 330 & - & .. \\
\hline $\mathrm{Gz}$ & 11 & $\$ 1$ & 14 & 12 & 11 & 9 & $<5$ & - & - \\
\hline $\mathrm{ZJ}_{\mathrm{J}}$ & 164 & 210 & 360 & 74 & 182 & 139 & 76 & $=$ & $\cdots$ \\
\hline a.j. & 1.093 & 1.023 & 0.951 & 1.012 & 1.339 & 1.286 & 1.081 & 0.840 & 1.061 \\
\hline D.J. & 90.30 & 92.58 & 92.53 & 92.88 & 86.64 & 88.95 & 91.40 & 87.09 & 89.94 \\
\hline$Q$ & 10.72 & 11.89 & 19.98 & 5.21 & 12.02 & 9.03 & 11.30 & 10.78 & 12.46 \\
\hline Or & 41.95 & 34.27 & 20.09 & 34.27 & 44.90 & 47.86 & 50.81 & 22.75 & 40.95 \\
\hline$A b$ & 37.64 & 46.42 & 52.46 & $\$ 3.10$ & 29.71 & 32.07 & 29.29 & 53.56 & 36.53 \\
\hline An & 0.00 & 0.00 & 1.97 & 0.00 & 0.00 & 0.00 & 0.00 & 7.51 & 0.00 \\
\hline $\mathrm{Ne}$ & 0.00 & 0.00 & 0.00 & 0.00 & 0.00 & 0.00 & 0.00 & 0.00 & 0.00 \\
\hline Ac & 2.60 & 1.60 & 0.00 & 0.93 & 3.76 & 2.16 & 3.76 & 0.00 & 2.86 \\
\hline Ms & 0.99 & 1.20 & 0.00 & 0.00 & 4.70 & 4.57 & 0.46 & 0.00 & 0.29 \\
\hline Di.Wo & $\{.87$ & 1.20 & 0.93 & 0.99 & 0.01 & 0.83 & 3.04 & 0.09 & 2.21 \\
\hline Di-En & 0.92 & 0.59 & 0.45 & 0.45 & 0.00 & 0.18 & 0.27 & 0.12 & 0.77 \\
\hline Di-l's & 0.92 & $0.5 B$ & 0.46 & 0.53 & 0.01 & 0.71 & 0.82 & 0.22 & 1.50 \\
\hline Hy-Ẽn & 0.15 & 0.03 & 0.22 & 0.00 & 0.82 & 0.17 & 0.15 & 0.25 & 0.00 \\
\hline $\mathrm{Hy}-\mathrm{Fs}$ & 0.15 & 0.03 & 0.22 & 0.00 & 1.31 & 0.67 & 0.46 & 0.18 & 0.00 \\
\hline Fo & 0.00 & 0.00 & 0.00 & 0.00 & 0.00 & 0.00 & 0.00 & 0.00 & 8.00 \\
\hline $\mathrm{Fa}$ & 0.00 & 0.00 & 0.08 & 0.00 & 0.00 & 0.00 & 0.00 & 0.00 & 0.00 \\
\hline Wo & 0.00 & 0.00 & 0.00 & 1.12 & 0.00 & 0.00 & 0.00 & 0.00 & 0.00 \\
\hline Mt & 0.00 & 1.08 & 1. $\$ 9$ & 0.94 & 0.00 & 0.00 & 0.00 & 1.22 & 0.00 \\
\hline II & 0.28 & 0.49 & 0.57 & 0.59 & 0.30 & 0.23 & 0.34 & 0.85 & 0.68 \\
\hline $\mathrm{Hm}$ & 0.00 & 0.30 & 0.58 & 0.53 & 0.00 & 0.00 & 0.00 & 0.00 & $0 . \Omega 0$ \\
\hline Ap & 0.24 & 0.17 & 0.17 & 0.19 & 0.26 & 0.12 & 0.33 & 0.28 & 0.47 \\
\hline $\mathrm{Cc}$ & 0.11 & 0.25 & 0.11 & 0.11 & 1.00 & 0.11 & 0.11 & 0.00 & 0.00 \\
\hline
\end{tabular}


Table $3-$ (continued)

\begin{tabular}{|c|c|c|c|c|c|c|c|c|c|c|}
\hline \\
\hline & IRF. I & TRF.2 & TRP.3 & TRF-4 & TRF.5 & TRF.6 & TRF-11 & TaP.12 & IRF-13 & IRP-14- \\
\hline $\mathrm{SiO}_{2}$ & 61.10 & 60.50 & 58.80 & 60.50 & 62.40 & 70.10 & 59.90 & 60.20 & 60.30 & 61.00 \\
\hline $\mathrm{THO}_{2}$ & 0.59 & 0.68 & 0.71 & 0.51 & & 0.32 & 0.46 & 0.34 & 0.40 & 0.50 \\
\hline $\mathrm{A}_{2} \mathrm{O}_{3}$ & 15.40 & 14.70 & 13.50 & $\$ 4.10$ & 14.00 & 13.00 & 14.90 & 14.50 & 14.70 & 15.20 \\
\hline $\mathrm{Fe}_{2} \mathrm{O}_{3}$ & 2.20 & 2.40 & 3.60 & 3.60 & 2.70 & 1.60 & 3.10 & 2.70 & 2.60 & 2.40 \\
\hline $\mathrm{FeO}$ & 1.00 & 1.30 & 2.30 & 1.30 & 1.15 & 1.15 & 1.15 & 1.30 & 1.22 & 0.80 \\
\hline $\mathrm{MgO}$ & 0.87 & 1.40 & 2.30 & 1.20 & 1.00 & 0.43 & 1.10 & 1.70 & 1.20 & 1.00 \\
\hline $\mathrm{CaO}$ & 2.70 & 3.00 & 4.10 & 3.00 & 2.60 & 1.50 & 2,60 & 3.50 & 3.00 & 2.50 \\
\hline $\mathrm{N}_{\mathrm{B}_{2} \mathrm{O}}$ & 2.40 & 2.80 & 3.50 & 3.80 & 3.70 & 2.60 & 3.80 & 3.20 & 3.10 & 2.70 \\
\hline $\mathrm{K}_{2} \mathrm{O}$ & 12.80 & 12.20 & 9.70 & 10.90 & 10.70 & 8.60 & 11.60 & 11.30 & 32.30 & 12.20 \\
\hline $\mathrm{P}_{2} \mathrm{O}_{5}$ & 0.32 & 0.26 & 0.33 & 0.26 & 0.27 & 0.11 & 0.28 & 0.33 & 0.29 & 0.20 \\
\hline $\begin{array}{l}\mathrm{CO}_{3} \\
\mathrm{CO}_{3}\end{array}$ & 0.05 & 0.05 & 0.05 & 0.11 & 0.11 & 0.05 & 0.05 & 0.05 & 0.07 & 0.00 \\
\hline $\begin{array}{l}\mathrm{U}_{2} \mathrm{O}^{+} \\
\mathrm{H}^{2}\end{array}$ & $0.1\}$ & 0.09 & 0.1 & 0.1 & 0.1 & 0.08 & 0.15 & 0.15 & 0.19 & 0.30 \\
\hline $\mathrm{H}_{2} \mathrm{O}^{\circ}$ & 0.13 & 0.13 & 0.20 & 0.10 & 0.10 & 0.09 & 0.18 & 0.02 & 0.01 & 0.00 \\
\hline Totel & 99.67 & 99.51 & 99.22 & 99.55 & 99.32 & 99.63 & 99.27 & 99.29 & 99.18 & 98.90 \\
\hline $\mathrm{Nb}$ & 20 & 20 & 20 & 20 & 20 & 20 & 20 & 20 & 20 & 20 \\
\hline Y & 10 & 10 & 36 & 10 & & 106 & 10 & 10 & & 10 \\
\hline B & 4.300 & 3.700 & 5.600 & 3.800 & .4 .600 & 2.700 & 4.600 & 6.000 & 4.400 & 5.550 \\
\hline$z_{n}$ & 28 & 31 & 90 & 52 & 53 & 51 & 46 & 46 & 44 & 30 \\
\hline $\mathrm{Rb}$ & 310 & 290 & 210 & 250 & $2 A_{0}$ & 340 & 240 & 250 & 280 & 310 \\
\hline SI & 540 & 420 & 650 & 410 & 500 & 370 & 750 & 590 & 560 & 550 \\
\hline $\mathrm{Ga}$ & 19 & 9 & 11 & 11 & 11 & 9 & 12 & 14 & 11 & 11 \\
\hline$z$ & 24 & 28 & 48 & 30 & 38 & 44 & 27 & 24 & 24 & 10 \\
\hline a.j. & 1.156 & 1.211 & 1.204 & 1.280 & 1.262 & 1.045 & 1.262 & 1.206 & 1.252 & 1.100 \\
\hline D.J. & $82.7 \%$ & 78.13 & 69.54 & 73.66 & 78.79 & 89.86 & 77.44 & 75.66 & 77.36 & 81.20 \\
\hline$Q$ & 0.00 & 0.00 & 0.00 & 0.00 & 3.36 & 20.40 & 0.00 & 0.00 & 0.00 & 0.00 \\
\hline 0 & 75.6 & 72.28 & 57 & 64.49 & & & 68.39 & 66.72 & 72.84 & 72.20 \\
\hline Ao & 4.4 & 4.0 & 8.86 & 9. & 12 & & & & & \\
\hline An & 0.0 & 0. & 0.0 & 0.0 & 0.0 & 0.0 & 0 & 0. & 0.00 & 0.00 \\
\hline $\mathrm{Ne}$ & 2. & 1. & & & & & & & & 1.20 \\
\hline 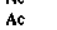 & 6. & 6. & 10.6 & 10.6 & & & & & & \\
\hline Ms & 0. & i. & 0.4 & $\begin{array}{r}3.0 \\
1.9\end{array}$ & & & & & & \\
\hline Di-Wo & 3. & 5. & 7. & & & & & & & \\
\hline Di-E & & & 4. & 3. & 2 & i. & 2 & 4 & 3.0 & 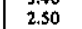 \\
\hline Dis & & & & & & & & & & \\
\hline $\mathrm{H} y \cdot \mathrm{En}$ & 0.0 & 0. & 0. & 0 & 0 & 0 & 0 & 0 & 0 & 0.00 \\
\hline $\mathrm{Hy} \cdot \mathrm{F}$ & 0.0 & 0 & 0. & & & & & & & 1.00 \\
\hline Fo & 0. & & 1. & 0. & 0. & & & 0. & 0.00 & 0.00 \\
\hline $\mathrm{F}$ & o. & 0. & & & & & & & & 0.00 \\
\hline $\begin{array}{l}\text { Wo } \\
\text { Wo }\end{array}$ & 1.7 & 0.52 & 0.0 & 1. & 1. & 1 . & 0. & 0. & 1.03 & 1.50 \\
\hline $\mathrm{Mi}$ & 0.8 & 0 & 0. & & & & & & 0.00 & .00 \\
\hline 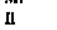 & 1. & 1. & 1 & & & . & & & & 1.00 \\
\hline $\mathrm{Hen}$ & 0.0 & 0.0 & 0. & 0 & & & B. & 0. & 0.00 & 0.00 \\
\hline$A_{P}$ & 0.62 & 0.62 & 0.67 & 0.67 & 0.67 & 0.31 & 0.62 & 0.62 & 0.62 & 0.62 \\
\hline Cc & 0.00 & 0.00 & 0.00 & 0.00 & 0.00 & 0.00 & 0.00 & 0.00 & 0.00 & 0.00 \\
\hline
\end{tabular}

DC, CAT $=$ Catingueira dyke DCG $=$ Campo Grande dyke; SER-63, $\mathrm{SM}=$ Macacos ring dyke; SER-44, SSA = Santo António dyke; $\mathrm{TRF}=$ Triunfo batholith. Major elements are found in $w t \%$ and trace elements, in ppm

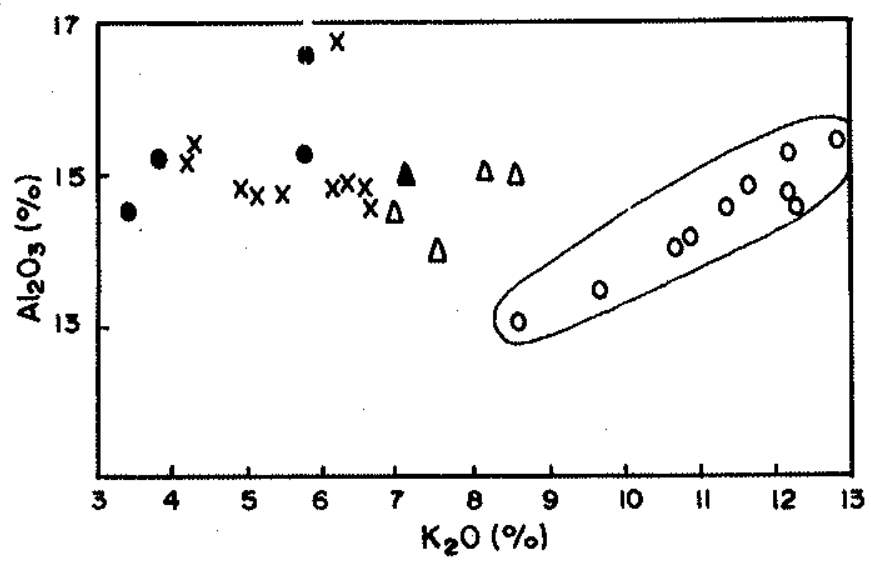

- Triunfo batholith

- Macocos ring dike

$\triangle$ Sonto António creek dike

- Campo Gronde dike

$x$ Cotingueira dike

Figure $\mathrm{S}-\mathrm{Al}_{2} \mathrm{O}_{3}$ vs. $\mathrm{K}_{2} \mathrm{O}$ diagram

Major and trace elements The Triunfo batholith exhibits an overall $\mathrm{SiO}_{2}$ variation from 58.8 to $62.4 \mathrm{wt} \%$, except for one sample (TRF-6), which exhibitted $70.1 \mathrm{wt} \%$ of $\mathrm{SiO}_{2}$. In the $\mathrm{OSG}, \mathrm{SSiO}_{2}$ lies. between 66.0 and 71.5 wt\% and $\mathrm{K}_{2} \mathrm{O}$ varies from 3.4 to $8.6 \mathrm{wt} \%$, while in the SG this oxide reaches contents between 9.7 and $12.8 \mathrm{wt} \%$. These very high contents result from the high concentration of K-feldspar (about 79\% of the volume of the rock) whose average $\mathrm{K}_{2} \mathrm{O}$ composition is around $14 \%$ (average $\mathrm{K}_{2} \mathrm{O}$ in aegirine is $0.19 \%$ only, according to Deer at al. 1966). The $\mathrm{Al}_{2} \mathrm{O}_{3}$ vs. $\mathrm{K}_{2} \mathrm{O}$ diagram (Fig. 5), where a positive correlation is attained, attests that the whole-rock $\mathrm{K}_{2} \mathrm{O}$ reflects the feldspar $\mathrm{K}_{2} \mathrm{O}$ contents (aegirine $\mathrm{Al}_{2} \mathrm{O}_{3}$ contents averages $1.85 \%$ only), and that the Triunfo syenite represents a cummulate rock.

In this body, $\mathrm{K}_{2} \mathrm{O}$ is always greater than $\mathrm{Na}_{2} \mathrm{O}$, with $\mathrm{K}_{2} \mathrm{O} / \mathrm{Na}_{2} \mathrm{O}$ ratios between 2.8 and 5.3. In the OSG, these ratios are lower, between 0.55 and 2.05. The $\mathrm{Fe}_{2} \mathrm{O}_{3}$ in the $\mathrm{SG}$ is greater than $\mathrm{FeO}$ and this reflects the presence of $\mathrm{Fe}^{3+}$-rich minerals as magnetite and aegirine.

In Figure 6, several oxides have been protted against $\mathrm{FeO}$, enhancing the differences between the OSG and SG. $\mathrm{P}_{2} \mathrm{O}_{5}$, $\mathrm{Na}_{2} \mathrm{O}$, and $\mathrm{K}_{2} \mathrm{O}$ plots suggest two independent population of samples, while $\mathrm{TiO}_{2}, \mathrm{MgO}$, and $\mathrm{CaO}$ plots failed to make such a distinction. FeO is clearly much higler in the SG. One sample (TRF-6) collected next to the contact in the Triunfo batholith often departs from the trends delineated by the other samples of this body. It shows much higher
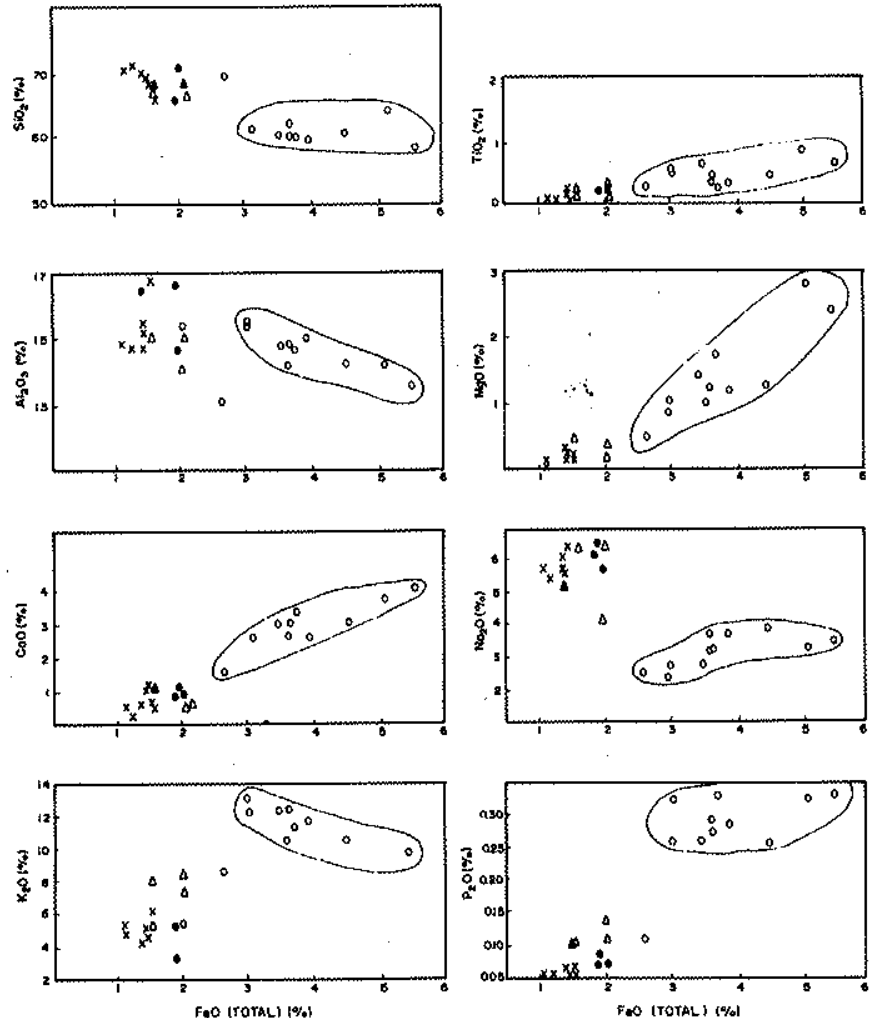

Loxend

- Triunso bolhothth

- Sorto Antonic croek dike

- Compo aronde dike

$x$ costnguatira diks

Figure 6 - Several oxides plotted against total $\mathrm{FeO}$ 
$\mathrm{SiO}_{2}$, lower $\mathrm{K}_{2} \mathrm{O}$ and $\mathrm{BaO}$, and as it exhibits a metamorphic fabric, may be it corresponds to a rock which underwent syenitization along the contact of the batholith (fenite).

Typically, the SG shows higher concentration of $\mathrm{MgO}$ and $\mathrm{CaO}$, which coupled with higher $\mathrm{FeO}$, suggests that these rocks keep a genetic link with a more mafic magma. In the Harker's diagram (Fig. 7), good correlations are usually attained with two distinct groups. Negative correlations are observed when $\mathrm{MgO}, \mathrm{CaO}, \mathrm{FeO}, \mathrm{Fe}_{2} \mathrm{O}_{3}$, and $\mathrm{K}_{2} \mathrm{O}$ against $\mathrm{SiO}_{2}$. In the alkali-lime Peacock's plot (Fig. 8), the $\mathrm{K}_{2} \mathrm{O}+\mathrm{Na}_{2} \mathrm{O}$ and $\mathrm{CaO}$ curves are about parallel to each other and do not allow determining the alkali-lime index. The negative trend from $60 \% \mathrm{SiO}_{2}$ up is typical for rocks in the alkaline series of Peacock.

Only eight trace elements - besides the REE group have been analysed for the two groups of rocks, $\mathrm{Sr}, \mathrm{Ba}$ and $\mathrm{Rb}$, found in very high concentrations much above average suggest that most rocks dealt with here represents feldspar cummulates. $\mathrm{Nb}, \mathrm{Y}, \mathrm{Zr}$, and $\mathrm{Zn}$, however, are found in very low concentrations if compared to values common to
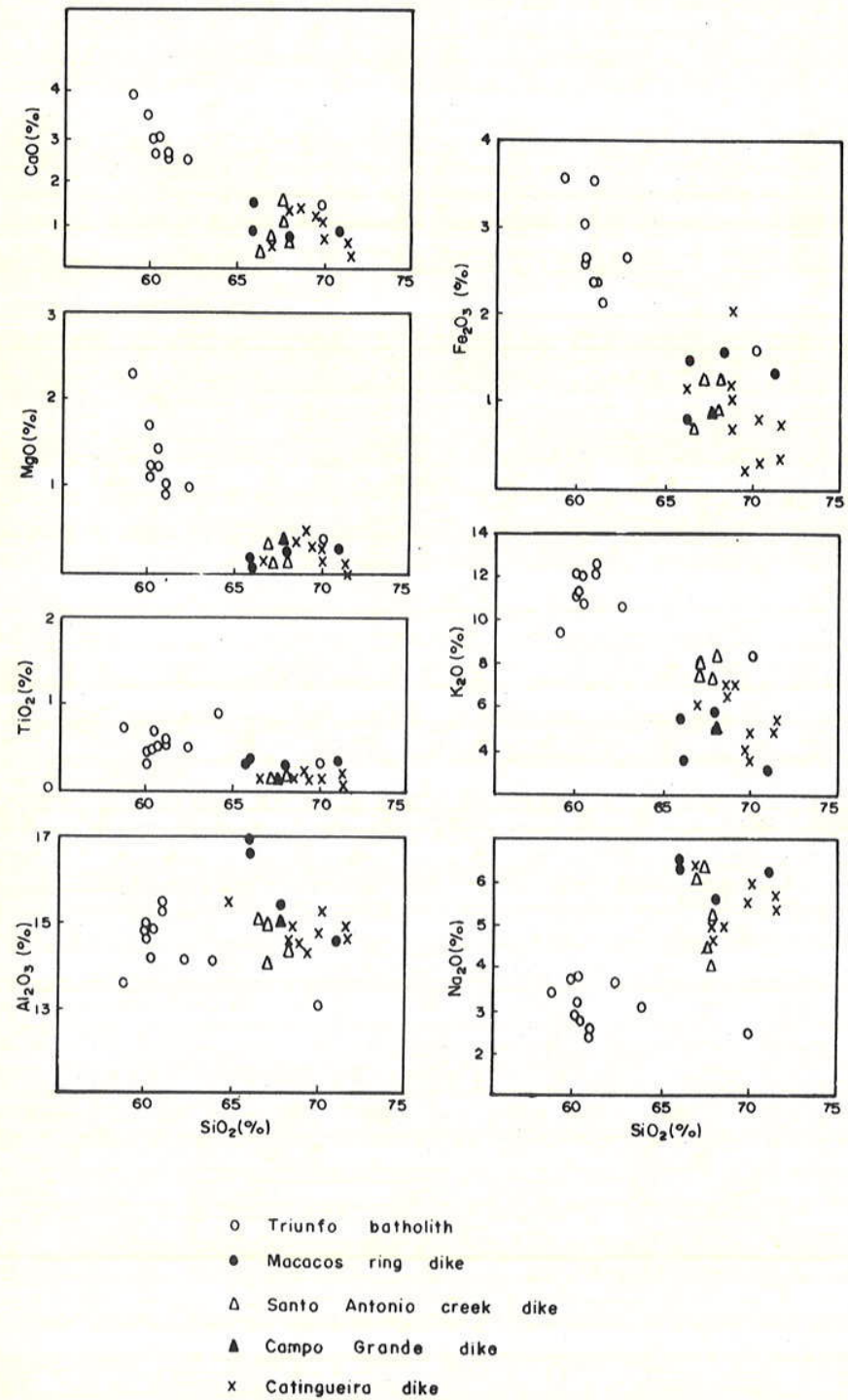

Figure 7 - Several oxides plotted against $\mathrm{SiO}_{2}$ (Harker's diagram)

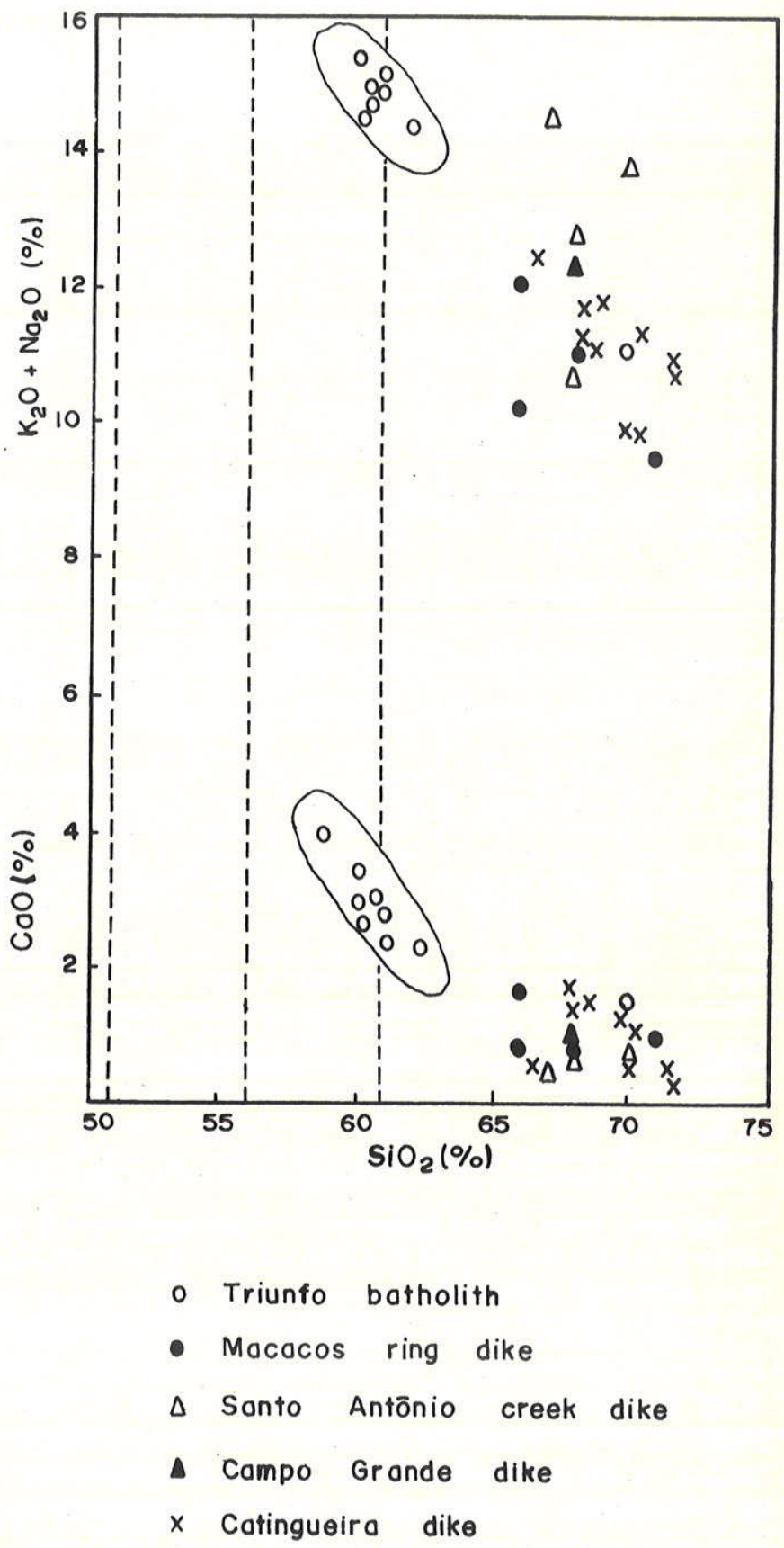

Figure 8-Peacock's alkali-line index diagram

peralkalic rocks (e.g. Topsails Complex, Newfoundland, Taylor \& Strong 1980, Nigeria-Niger province, Bowden \& Turner 1974). Likely, accessory phases containing $\mathrm{Zr}, \mathrm{Nb}$, and $\mathrm{Y}$ have been fractionated out of the liquid (e.g. zircon). As zircon is virtually absent or found only in very low amounts, it is possible that this phase has been continuously left behind during magma ascent, causing these elements to be substantially dropped down.

Rare-earth elements Eleven samples had their REF analysed at the Geosol Laboratory. As a standard analytical procedure, they have been concentrated by ion-exchange chromatography and then analysed by plasma spectrometry (ICP, according to the method described by Dutra 1984). Four other samples (all from the Catingueira dike) have 
Table 4 - Rare-earth elements of peralkalic rocks in the Cachoeirinhasalgueiro foldbelt, Northeast Brazil

\begin{tabular}{|c|c|c|c|c|c|c|c|c|}
\hline \multicolumn{9}{|c|}{ OVERSATURATED ROCKS } \\
\hline & DC-1" & DC-5* & DCG-1* & CAT-1** & CAT-2** & CAT-5** & CAT-6"* & SM-2* \\
\hline La & $20.61(84.26)$ & $14.61(59.73)$ & $30.59(125.06)$ & $28.72(117.42)$ & $24.40(99.75)$ & $27.35(111.81)$ & $25.54(104.41)$ & $80.37(328.58)$ \\
\hline $\mathrm{Ce}$ & $34.10(53.46)$ & $28.10(44.05)$ & $47.60(74.62)$ & $74.68(117.07)$ & $51.81(81.22)$ & $62.77(98.40)$ & $54.00(84.65)$ & $139.80(219.16)$ \\
\hline Nd & $16.87(35.61)$ & $14.43(30.46)$ & $20.38(43.01)$ & $36.83(77.73)$ & $23.18(48.92)$ & $28.09(59.29)$ & $26.89(56.75)$ & $59.87(126.36)$ \\
\hline $\mathrm{Sm}$ & $3.60(23.38)$ & $3.58(23.25)$ & $4.38(28.44)$ & $9.53(55.39)$ & $4.86(31.56)$ & $5.77(37.47)$ & $5.81(37.73)$ & $12.48(81.04)$ \\
\hline $\mathrm{Eu}$ & $0.94(16.20)$ & $0.91(15.68)$ & $1.05(18.09)$ & $2.57(50.57)$ & $1.69(33.25)$ & $1.88(32.40)$ & $2.06(40.53)$ & $2.91(50.15)$ \\
\hline Gd & $2.22(10.87)$ & $2.54(12.43)$ & $2.73(13.36)$ & $6.69(32.75)$ & $3.50(17.13)$ & $4.11(20.12)$ & $4.39(21.49)$ & $6.75(33.04)$ \\
\hline Dy & $1.51(5.94)$ & $2.02(7.95)$ & $1.85(7.28)$ & $4.41(17.35)$ & $2.19(8.62)$ & $2.62(10.31)$ & $2.77(10.90)$ & $3.86(15.19)$ \\
\hline Ho & $0.16(2.82)$ & 0.17 ( 2.99$)$ & $0.18(3.17)$ & $0.74(13.05)$ & $0.26(4.59)$ & $0.36(6.35)$ & 0.17 ( 2.99) & $0.57(10.05)$ \\
\hline Er & $0.41(2.47)$ & $0.36(2.17)$ & $0.33(1.99)$ & $1.88(11.32)$ & $0.78(4.70)$ & $0.99(5.96)$ & $1.10(6.63)$ & $1.34(8.07)$ \\
\hline $\mathrm{Tm}$ & $0.06(2.34)$ & $0.07(2.73)$ & $0.07(2.73)$ & - & - & - & - & $0.18(7.03)$ \\
\hline $\mathrm{Yb}$ & $0.55(3.33)$ & $0.79(4.78)$ & $0.69(4.18)$ & $1.33(8.06)$ & $0.40(2.42)$ & $0.26(1.57)$ & $0.55(3.33)$ & $1.45(8.78)$ \\
\hline Lu & $0.08(3.15)$ & $0.15(5.51)$ & $0.09(3.54)$ & - & - & - & - & $0.21(8.27)$ \\
\hline EREE & 81.11 & 67.72 & 109.44 & 166.38 & 67.07 & 78.45 & 75.74 & 309.79 \\
\hline $\mathrm{La}_{\mathrm{n}} / \mathrm{Sm}_{\mathrm{n}}$ & 3.60 & 2.57 & 4.39 & 2.10 & 3.13 & 2.96 & 2.74 & 4.05 \\
\hline $\mathrm{Ce}_{\mathrm{n}} / \mathrm{Yb}_{\mathrm{n}}$ & 16.05 & 9.21 & 17.85 & 14,35 & 33.18 & 62.26 & 24.97 & 24.96 \\
\hline $\mathrm{Eu} / \mathrm{Eu}^{*}$ & 0.94 & 0.87 & 0.86 & 1.02 & 1.22 & 1.15 & 1.22 & 0.88 \\
\hline
\end{tabular}

\begin{tabular}{|c|c|c|c|c|c|c|c|}
\hline \multicolumn{8}{|c|}{ SATURATED ROCKS } \\
\hline & SM-3" & SSA-2* & TRF-2 & TRF-3 & TRF-6 & TRF-11 & TRF-14 \\
\hline $\mathrm{La}$ & $60.03(245.42)$ & $16.44(67.21)$ & $39.41(161.12)$ & $67.62(276.45)$ & $44.10(180.29)$ & $33.29(163.10)$ & $19.03(77.80)$ \\
\hline $\mathrm{Ce}$ & $120.90(189.53)$ & $32.60(51.11)$ & $80.00(125.41)$ & $123.10(192.98)$ & $63.30(99.23)$ & $56.50(88.57)$ & $40.00(62.71)$ \\
\hline Nd & $60.63(127.96)$ & $14.71(31.05)$ & $37.34(78.81)$ & $60.77(128.26)$ & $39.14(82.61)$ & $27.85(58.78)$ & $18.02(38.03)$ \\
\hline $\mathrm{Sm}$ & $12.63(82.01)$ & $3.43(22.72)$ & 11.08 ( 71.95$)$ & $15.65(101.62)$ & $11.49(74.61)$ & $6.64(43.12)$ & $5.05(32.79)$ \\
\hline $\mathrm{Eu}$ & $2.91(50.15)$ & $0.89(15.34)$ & $1.98(34.13)$ & $3.04(52.39)$ & $1.37(23.61)$ & $1.18(20.34)$ & $0.97(16.72)$ \\
\hline Gd & $6.68(32.69)$ & $2.28(11.16)$ & $6.21(30.39)$ & $10.42(51.00)$ & $10.05(49.19)$ & $3.68(18.01)$ & $2.90(14.19)$ \\
\hline Dy & $3.31(13.03)$ & $1.94(7.63)$ & $3.94(15.51)$ & $6.98(27.47)$ & $10.02(39.43)$ & $1.83(7.20)$ & $1.76(6.93)$ \\
\hline Ho & $0.46(8.11)$ & $0.18(3.17)$ & $0.40(7.05)$ & $1.54(2.72)$ & $2.69(47.44)$ & $0.36(6.35)$ & $0.24(4.23)$ \\
\hline Er & $0.85(5.12)$ & $0.64(3.85)$ & $0.99(5.96)$ & $3.54(21.32)$ & $7.29(43.92)$ & $0.85(5.12)$ & $0.56(3.37)$ \\
\hline $\operatorname{Tm}$ & $0.14(5.47)$ & $0.10(3.90)$ & $0.12(4.68)$ & $0.42(16.40)$ & $1.08(42.17)$ & $0.13(5.08)$ & $0.10(3.90)$ \\
\hline $\mathrm{Yb}$ & $0.83(5.03)$ & $0.96(5.81)$ & $0.98(5.94)$ & $2.54(15.38)$ & $5.37(32.53)$ & $0.59(3.57)$ & 0.50 ( 3.03$)$ \\
\hline $\mathrm{Lu}$ & $0.11(4.33)$ & $0.16(6.30)$ & $0.11(4.33)$ & $0.39(15.36)$ & $0.83(32.69)$ & $0.16(6.30)$ & $0.70(2.76)$ \\
\hline$\Sigma$ REE & 269.48 & 74.33 & 182.56 & 296.01 & 196.73 & 133.06 & 89.20 \\
\hline $\mathrm{La}_{\mathrm{n}} / \mathrm{Sm}_{\mathrm{n}}$ & 2.99 & 3.02 & 2.24 & 2.72 & 2.42 & 3.78 & 2.37 \\
\hline $\mathrm{Ce}_{\mathrm{n}} / \mathrm{Yb}_{\mathrm{n}}$ & 37.68 & 8.79 & 21.11 & 12.55 & 3.05 & 24.81 & 20.69 \\
\hline $\mathrm{Eu} / \mathrm{Eu}{ }^{*}$ & 0.87 & 0.92 & 0.66 & 0.68 & 0.38 & 0.66 & 0.71 \\
\hline
\end{tabular}

* = Performed in the Geosol Laboratory; ${ }^{*}$ * $=$ performed by A.N. Sial, in Newfoundland, Canadá; DC, CAT = Catingueira dike; DCG = Campo Grande dike; SM = Macacos ring dike; SSA = Santo Antonio creek (Minador) dike; TRF = Triunfo batholith; REE are in ppm; numbers in parentheses are normalized to chondrite

been analysed by one of the authors (ANS) through the X-ray fluorescence method, at the Department of Geological Sciences, Memorial University of Newfoundland, Canada. In this procedure, the REF group was concentrated by ion-exchange chromatography, and then placed in an SA-2 ion-exchanged paper, before analysing by XRF, using a tungsten tube. The chondrite values used were those of Evensen et al. (1978). Results are listed in table 4 and relative abundance patterns for each of two groups are showning in figure 9.

The two groups of rocks here studied are characterized by a strong relative enrichment of the light REF, compared to the average chondrite values and depleted in heavy REF, in relation to the light rate-earths, in a patterns of negative slope.

The saturated peralkalic rocks, except for one sample (TRF-6), which presents a strong negative Eu anomaly $\left(\mathrm{Eu} / \mathrm{Eu}^{*}=0.38\right)$, are characterized by discrete negative $\mathrm{Eu}$ anomaly $\left(\mathrm{Eu} / \mathrm{Eu}^{*}\right.$ varies from 0.66 to 0.71$)$. There is a tendency for an increase of the $\Sigma$ REE with the decrease of $\mathrm{SiO}_{2}$ and $\mathrm{K}_{2} \mathrm{O}, \mathrm{CaO}$ showing opposite behavior. The $\Sigma \mathrm{REE}$ varies from 89.2 to $296 \mathrm{ppm}$. The patterns for the oversaturated peralkalic rocks depart from the ones usually observed for this kind of rocks (see for exemple Bowden \&
Whitley 1974). They lack the typical deep negative $\mathrm{Eu}$ anomaly. On the contrary, Eu anomaly is either missing or slightly positive (Eu/Eu* varies from 0.86 to 1.199$)$. The $\Sigma$ REE varies from 67.07 to $309.79 \mathrm{ppm}$ (samples from Macacos hill ring-dike are much higher in $\Sigma$ REE).

The missing $\mathrm{Eu}$ anomaly may be reflects a rather high oxygen fugacity, once the feldspar $\mathrm{Eu}$ anomaly decreases with the $\mathrm{FO}_{2}$ and temperature increase (Drake 1975, Hanson 1980). Sial (1984a) had already called attention to this problem, pointing out that the K-feldspar fractionation had been responsible for the peralkalinity of the Catingueira body and this process did not generate the usually observed negative Eu anomaly. The crystallization of these rocks took place at relatively high oxygen fugacity, precluding $\mathrm{Eu}$ to enter the structure of the feldspar, as usually. These rocks probably represent the stage were $\mathrm{K}$-feldspar crystallized was not removed from the liquid, characterizing a transitional situation for a peralkaline stage.

Almost all samples of this group display a discrete negative $\mathrm{Er}$ anomaly $\left(\mathrm{Er} / \mathrm{Er}^{*}\right.$ from 0.34 to 1.0$)$. There is a possibility that fractionation of Ta-rich minerals (fergusonite and/or yttrotantalite, Er-rich phases) has been responsible for such an anomaly, or that it is only an 

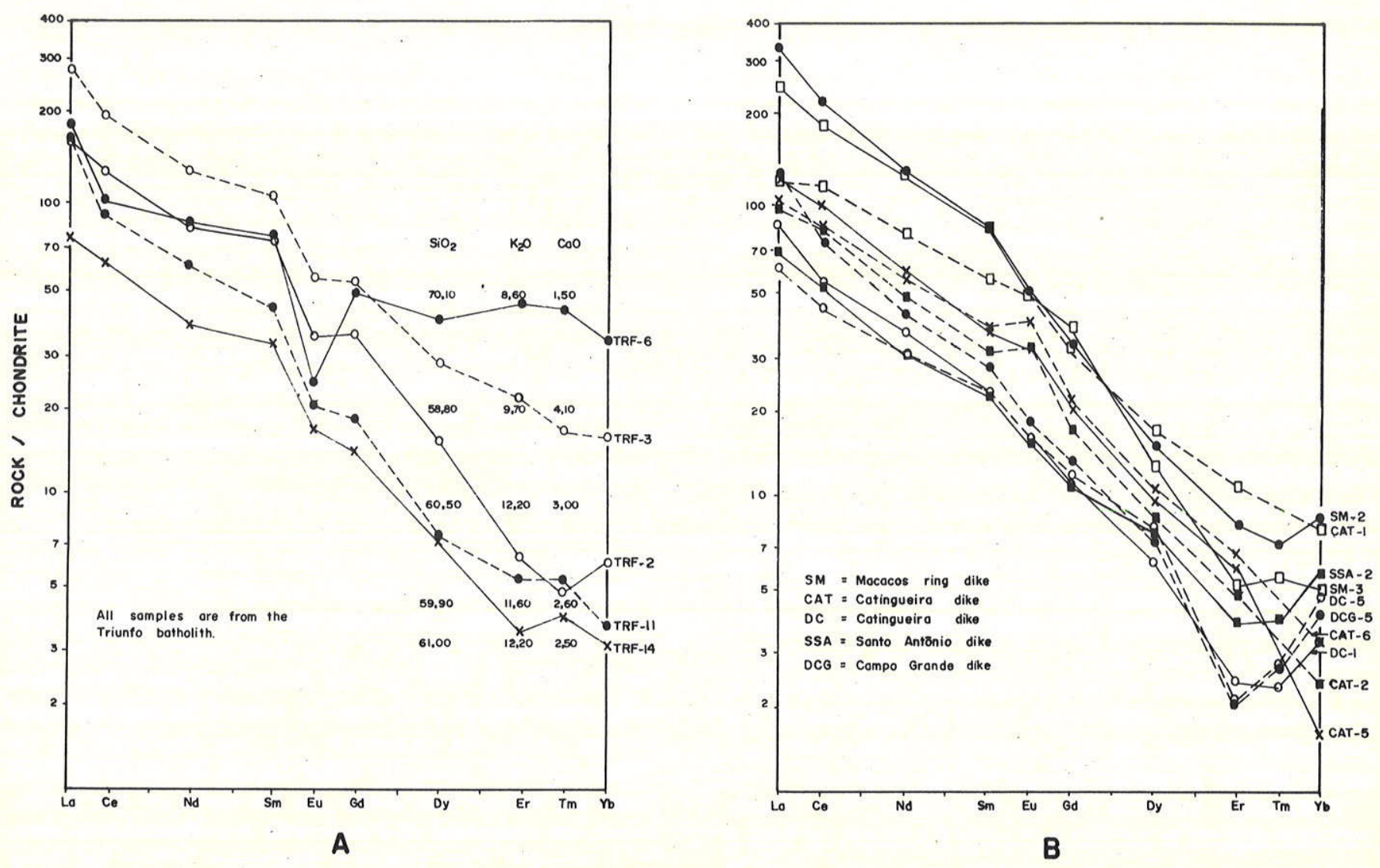

Figure 9 - Chondrite-normalized REE patterns. A: saturated rocks; $\mathrm{B}$ : oversaturated rocks. $\mathrm{SiO}_{2}, \mathrm{CaO}$ and $\mathrm{K}_{2} \mathrm{O}$ values for $\mathrm{B}$ rocks in diagram $B$ can be found in table 3

apparent one, due to slight $\mathrm{Yb}$ and $\mathrm{Lu}$ enrichment in consequence of garnet in the residue of the melting in the source area. The likelihood of analytical error cannot be discarded.

Oxygen isotopes All oxygen isotope analyses were performed by reaction with fluorine at the Department of Geology, University of Georgia, in Athens, USA, by one of the authors (ANS). Isotope analyses were made using a VG Micromass $602 \mathrm{C}$ double collecting mass spectrometer. Routine intercomparisons of samples with Rose quartz standard were made, the standard being defined as +8.45 permil relative to SMOW. Results are found in table 5 ..

An overview of the whole-rock oxygen data shows that the Catingueira body and border of the Salgueiro body exhibit values below 10 permil, while the dikes of the Santo Antônio Creek, about $30 \mathrm{~km}$ north of Serrita, show $\delta^{18} \mathrm{O}$ above 10 permil. These divergences could be ascribed to: $(a)$ differences in the isotope composition of the protoliths; $(b)$ different degree of differentiation; and $(c)$ late alteration by interaction with meteoric water. Due to the limited amount of data, it is hard to decide which one of these hypotheses is true.

Although it is very important to analyse mineral separates to test if the whole-rock $\delta^{18} \mathrm{O}$ is original, only four samples had quartz and feldspar analysed and one of them (CAT-5) revealed an inversion, with feldspar heavier than quartz in terms of oxygen isotope ratios. In this case,
Table 5 - Oxygen isotope analyses of peralkalic dikes in the Cachoeirinha-Salgueiro foldbelt

\begin{tabular}{|c|c|c|c|c|c|}
\hline Sample & Rock type & $\begin{array}{c}\text { W.R. } \\
\delta^{180} \\
\text { (SMOW) }\end{array}$ & $\begin{array}{c}\text { Quartz } \\
\delta^{180} \\
\text { (SMOW) }\end{array}$ & $\begin{array}{c}\text { Feldspar } \\
\delta^{180} \\
\text { (SMOW) } \\
\end{array}$ & Locality \\
\hline $\begin{array}{l}\text { SER-43 } \\
\text { SER-44 }\end{array}$ & $\begin{array}{l}\text { Subvolcanic fine-grained } \\
\text { riebeckite-aegirine-bearing } \\
\text { rocks }\end{array}$ & $\begin{array}{l}+12.21 \\
+10.60\end{array}$ & $\overline{-}$ & $\overline{-}$ & \begin{tabular}{|l|} 
Santo Antônio \\
Creek (Minador) \\
$30 \mathrm{~km}$ north of \\
Serrita, Pernambuco \\
\end{tabular} \\
\hline SER-63 & Aegirine-bearing granite & +9.66 & - & - & $\begin{array}{l}\text { Macacos hill, Serrita } \\
\text { Pernambuco (ring-dike) }\end{array}$ \\
\hline $\begin{array}{l}\text { CAT-1 } \\
\text { CAT-2 } \\
\text { CAT-5 } \\
\text { CAT-6 }\end{array}$ & $\begin{array}{l}\text { Aegirine-bearing } \\
\text { Quartz-alkali-feldspar } \\
\text { syenite }\end{array}$ & $\begin{aligned} &+ 8.69 \\
&+ 9.35 \\
&+ 9.81 \\
&+ 8.12 \\
&\end{aligned}$ & $\begin{array}{l}+8.80 \\
+8.67 \\
\end{array}$ & $\begin{array}{r}+8.45 \\
+10.37 \\
-\end{array}$ & $\begin{array}{l}\text { Catingueira dike, } \\
\text { Paraíba }\end{array}$ \\
\hline $\begin{array}{l}\text { S- }-07 \\
\text { S-12 } \\
\text { S-20 } \\
\text { S-30 }\end{array}$ & $\begin{array}{l}\text { Ferroaugite-quartz } \\
\text { syenite }\end{array}$ & $\begin{array}{l}+8.92 \\
+\quad 9.95 \\
+9.93 \\
+\quad 9.35\end{array}$ & $\begin{array}{l}+11.75 \\
+\overline{2} .22\end{array}$ & $\begin{array}{l}+8.92 \\
+\overline{9} .92\end{array}$ & $\begin{array}{l}\text { Eastern porton of the } \\
\text { the Salgueiro batholith, } \\
\text { Pernambuco }\end{array}$ \\
\hline
\end{tabular}

the whole-rock $\delta^{18} \mathrm{O}$ is useless for petrogenetic purposes. If, however, the other values are igneous ones, then there are two populations of peralkalic rocks in this area. One whose oxygen values are below 10 permil and other whose values are above this, a critical value to tell apart igneous-source derived rocks from those metasedimentary-source derived (O’Neil et al. 1977).

The dikes of the Santo Antônio Creek and the Catingueira dike cut the Cachoeirinha Group metasediments and the discrepancy observed is not apparently related to differences in host rocks as could be claimed. The ring-dike of the Macacos hill intruded rocks with trondhjemitic 
affinities shows $\delta^{18} \mathrm{O}$ below 10 permil and seems to belong to the same group of peralkalic rocks of the Catingueira-type, that is, probably derived from the mantle or igneous source with minor, if any, metasedimentary component. The Santo Antônio Creek dikes, however, may have derived from metasedimentary source or have had substantial crustal contribution, judging from their high $\delta^{18} \mathrm{O}$. Being a subvolcanic body, the possibility of interaction with meteoric water cannot be excluded.

Rocks of the eastern portion of the Salgueiro batholith with peralkalic affinities (ferroaugite-quartz syenites) show $\delta^{18} \mathrm{O}$ values below 10 permil and are here considered, in terms of oxygen isotopes, equivalent to the Catingueira body, probably of similar derivation.

DISCUSSION A series of geological and petrological features make the peralkalic magmatism in the CSF attractive and worth studying. A number of peralkalic bodies (Triunfo, Bom Nome, and Paulo, Duas Irmãs, Casé and Livramento ridges), most syenitic in composition, and bodies with peralkalic affinities (Teixeira \&. Solidão) constitutes a trend adjacent to the southern boundary of the CSF. Magnetite is the predominating oxide mineral in these bodies and they form what is here named the peralkalic-syenitoid line or magnetite-syenitoid belt in a similar fashion to Ishihara's magnetite-granitoid belt.

Pyroxenite autoliths found throughout the Triunfo batholith suggest important pyroxene fractionation from a pyroxenite or alkaline basic magma. Composed autoliths (pyroxenite and gray K-feldspar cummulate) suggest a layered structure for the batholith and that underneath the syenite, a volume of early fractionated pyroxenite was formed. Sulphides in these autoliths perhaps indicate sulphide concentration at depth, in the pyroxenite.

The unusually high $\mathrm{Ba}$ and $\mathrm{Sr}$ contents indicate that, in most cases, these rocks represent $\mathrm{K}$-feldspar cummulates. The REE signatures reflect a rather high oxygen fugacity prevailing during crystallization, precluding significant Eu anomaly to develop. Er anomaly in a few analyses could result from fractionation of an accessory phase or just be the consequence of analytical problems. The rather low $\mathrm{Nb}$ suggests that either a $\mathrm{Nb}$-rich phase was fractionated out of the liquid or that magma was originally low in $\mathrm{Nb}$.

In the light of available oxygen isotope ratios, it seems that most of the peralkalic bodies is mantle-derived or resulted from partial melting of igneuos protolith, except for the dikes next to Santo Antônio.

The very high $\mathrm{K}_{2} \mathrm{O}$ in the Triunfo syenite suggests the magma derived from an anomalous mantle or igneous source with high potassium content. The K-enrichment in the mantle is well documented, as for exemple through richterite-bearing peridotite xenoliths in kimberlites (Erlank 1976).
Alkali-trachytes is usually regarded as derived from alkaline basic magmas by crystal fractionation at high level in the crust. The volume of these salic lavas in many continental provinces equals or exceeds that of possible parent basic magmas, and this has led to the assumption of an origin by partial melting in the upper mantle (Wright 1969), to account for the excessive amount of these rocks. The large volume of syenite at Triunfo and other bodies in the syenitoid line is an awkward problem to account for in the alkaline basic magma model, which, however, should not be totally ruled out. The possibility of an alkali trachyte magma fractionating early pyroxene is a hypothesis which should be considered. Any of these two hypotheses that stands further detailed isotopic work at Triunfo will be valid for the other syenite bodies in the syenitoid line.

Oversaturated rocks as Catingueira, Urtiga and Campo Grande may have a different history and it is difficult, presently, to evaluate the crustal participation on their formation, without a reliable isotopic data. The Teixeira and Solidão batholiths with slight peralkalic affinity may have different petrogenesis. The Macacos hill ring-dike with much higher $\Sigma$ REF and the Santo Antônio Creek dikes with much higher $\delta^{18} \mathrm{O}$ may be formed through different process and the possibility of late modification by interaction with meteoric water cannot be excluded once these are subvolcanic rocks. As the cores of the Serrita stocks are composed of a rock with trondhjemitic affinity, it is possible that Bowen's plagioclase effect has been responsible for the peralkalinity observed in the associated ring-dikes.

Narrow, fine-grained dikes of identical composition to the Triunfo batholith which crosscut it suggest a dilatation process at the end of the crystallization of the batholith, as auto-intrusion. This implies that this batholith was late-tectonically emplaced as well as the other syenites of this nature in the peralkalic syenitoid line.

Recently, J.V. Valarelli (oral communication) developed a way to use potassium from K-feldspar as fertilizer and this potentially lends these syenites some economic importance, since they are extremely enriched in potassium and occupy quite a large volume.

Acknowledgements. We are indebted to the Finep Agency (Financiadora de Estudos e Projetos) which through the PADCT program partially supported this study. Our gratitude is also directed to the Conselho Nacional de Desenvolvimento Cientifico e Tecnológico $(\mathrm{CNPq})$ for the grant-in-aid to one of us (ANS), which covered the first expenses with the field work.

\section{REFERENCES}

ALMEIDA, A.R. de; SIAL, A.N.; FERREIRA, V.P. - 1984 Petrologia e geoquímica de enxames de diques Cambrianos do Nordeste do Brasil. In: SIMP. GEOL. NORDESTE., 11, Natal, 1984. Atas..., Natal, SBG/NNE, p. 60-77.

ALMEIDA, F.F.M. de; LEONARDOS, O.H.; VALENÇA, J. - 1967 - Review on granitic rocks of Northeast South America. In: IUGS/UNESCO SYMPOSIUM, Recife, 1976, Spec. Publ..., Recife, IUGS/UNESCO, $41 \mathrm{p}$
ARAÛJO NETO J.G. de $-1982 \rightarrow$ Contribuicão d geologia de parte do Município de São José do Belmonte, Pernambuco, área 18. Recife, (relatorio de graduação em Geologia, inédito), Univ. Federal de Pernambuco, Dept. Geol., Conv. Min. PE/UFPE, 80 p.

ASSUNÇĀO, P.G.S. de - 1983 - Mapa geológico do Cinturão Móvel Transversal e áreas adjacentes. In: CPRM-SUREG, Programa para levantamentos e avaliações de recursos minerais. Recife. (escala 1/660.000). 
BARBOSA, O. - 1970 - Geologia econômica de parte da região do Médio Säo Francisco, Nordeste do Brasil. Rio de Janeiro. (DNPM/DFPM, Bol. 140), $97 \mathrm{p}$

BORBA, G.S. \& SIAL, A.N. - 1979 - Estudo petrológico e petroquímico do granito de Cabo de Santo Agostinho, Pernambuco. In: SIMP. GEOL. NORDESTE, 9, Natal, 1978. Atas..., Natal, SBG/NNE, Bol. 7. p. 306-316.

BOWDEN, P. \& TURNER, D.C. - 1974 - Peralkaline and associated ring-complexes in the Nigeria-Niger province, West Africa. In: SORENSEN, H. (ed.) The alkaline rocks. New York, John Wiley \& Sons, p. 330-351.

BOWDEN, P. \& WHITLEY, J.E. - 1974 - Rare-earth patterns in peralkaline and associated granites. Lithos, 7:15-21.

BRITO NEVES, B.B. de - 1975 - Regionalização geotectônica do Precambriano Nordestino. São Paulo, (Tese de Doutoramento IGUSP, inédita). $198 \mathrm{p}$.

BRITO NEVES, B.B. de - 1983 - O mapa geológico do Nordeste Oriental do Brasil, escala 1/1.000.000. São Paulo, (Tese de Livre-Docência IGUSP, inédito). $117 \mathrm{p}$.

CALDASSO, A.L. da S. - 1967 - Geologia da Quadricula 094E-Folha Crato. Recife. SUDENE, Div. de Docum., 35 p. (Série Geologia Regional).

DEER, F.R.S.; HOWIE, R.A.; ZUSSMAN, J. - 1966 - An introduction to the rock-forming minerals. London, Logman, $528 \mathrm{p}$.

DRAKE, M.J. - 1975 - The oxidation state of europium as an indicator of oxygen fugacity. Geoch. Cosmoch. Acta, 39:55-64.

DUTRA, C.V. - 1984 - Método para determinação de traços e subtraços de terras-raras em rochas por espectrometria de plasma (ICP) - Aplicacão em petrogênese. In: CONGR. BRAS. GEOL., 33, Rio de Janeiro, 1984. Anais..., Rio de Janeiro, SBG, p. 4792.

ERLANK, A.J. - 1976 - Upper mantle metasomatism as revealed by potassic richterite-bearing peridotite xenoliths from kimberlite. EOS, 57:579.

EVESEN, N.M.; HAMILTON, P.J.; O'ONIONS, R.K. - 1978 Rare-earth abundances in chondritic meteorites. Geoch. Cosmoch. Acta, 42:1199-1212.

HADDAD, R.C. \& LEONARDOS, O.H. - 1980 - Granitos anelares de Taperuaba, Ceará, e processos metassomáticos associados. In:CONGR. BRAS. GEOL., 31, Camboriú, 1980. Anais..., Camboriú, SBG, v. 2, p. 2626-2633.

HANSON, G.N. - 1980 - Rare-earth elements in petrogenetic studies of igneous systems. Ann. Rev. Earth Planet. Sci. 8:371-406

ISHIHARA, S. - 1977 - The magnetic-series and ilmenite-series granitic rocks. Min. Geol., 27:293-305.

LONG, L.; SIAL, A.N.; NEKVASIL, H.; BORBA, G.S. - (in press) - Origin of granite at Cabo de Santo Agostinho, Northeast Brazil. Contr. Min. Petrol.

MAIOR, I.S. - 1980 - Geologia de uma área a SE de Salgueiro, PE., Recife, (relatório de graduação em Geologia, inedito). Dept Geol. Conv. DNPM/UFPE. 116p.

MELLO, A.A. de \& ASSUNÇĀO, P.R.S. - 1984 - o cinturão móvel transversal: Especulaçōes sobre uma possível evolução à luz da tectônica global. In: CONGR. BRAS. Geol., 33, Rio de Janeiro, 1984. Anais..., Rio de Janeiro, SBG, p. 3348-3361.

MOURA, F.A.P. de - 1983 - Projeto mapeamento geológico básico da regiäo centro-oeste do Estado de Pernambuco, Folha Säo José do Belmonte, SB.24-Z.C-IV, área 19. Recife, (relatorio de graduação em Geologia, inédito). Univ. Fed. Pernambuco, Dept. Geol. Conv. Min. PE/UFPE, 80 p.

O'NELL, J.R.; SHAW, S.E.; FLOOD, R.H. - 1977 - Oxygen and hydrogen isotope compositions as indicator of granite genesis, in the New England batholith, Australia. Contr. Min. Petrol., 62:313-325.

SĀ, J. de - 1982 - Contribuiçăo à geologia de parte dos munictpios de Salgueiro, Verdejante e Mirandiba, Pernambuco, Recife, (re latório de graduação em Geologia, inédito), Univ. Fed. Pernambuco, Dept. Geol. Conv. Min. PE/UFPE, 93 p.

SADOWSKI, G.R. - 1973 - O batólito quartzo-sientitico da Serra da Baixa Verde, Pernambuco. Bol. Inst. Geociências, Univ. São Paulo, 4:39-46.
SANTOS, E.J. dos - 1971 - As feições estruturais da folha Arcoverde, Pernambuco. Rev. Min. Met., 35:39-46.

SIAL, A.N. - 1984a - Litogeoquímica de elementos terras-raras na caracterização de granitóides do espaço Cachoeirinha, Nordeste do Brasil, In: CONGR. BRAS. GEOL,, 33, Rio de Janeiro, 1984. Anais..., Rio de Janeiro, SBG, p. 2697-2709.

SIAL, A.N. - 1984b - Padrão regional de isótopos de oxigênio em granitóides do espaço Cachoerinha, Nordeste do Brasil. In: CONGR. BRAS. GEOL., 33, Rio de Janeiro, 1984. Anais..., Rio de Janeiro, SBG, p. 2710-2722.

SIAL, A.N. \& MENOR, E.A. - 1969 - Contribuiçäo à geologia da Meia Quadricula Este de Âfogados da Ingazeira, PE. Recife (relatório para o Conselho Nacional de Pesquisas - CNPq). 22 p. (inédito).

SIAL, A.N.; BORBA, G.S.; VILLARROEL, H.S.; ALBUQUERQUE, C.A.R. - 1980 - Geoquímica de elementos terras-raras do granito do Cabo de Santo Agostinho, Pernambuco. In: CONGR. BRAS. GEOL., 31, Camboriú, 1980. Anais..., Camboriú, SBG, v. 2, p. 2285-2299.

SIAL, A.N.; LIMA, E.S. de; PESSOA, D.A.; CASTRO, C. de; VILLARROEL, H.S.; RODRIGUES DA SILVA, M.R.; BORBA G.S.; LIMA, G.R. - 1981 a - Geoquímica de dois stocks granodioríticos de Serrita, Pernambuco: elementos maiores. In: ESTUDOS GEOLÓGICOS, Recife, Univ. Fed. Pernambuco, Centro de Tecnologia, $91 \mathrm{p}$.

SIAL, A.N.; PESSOA, D.A.; LIMA, E.S.; VILLARROEL, H.S.; CASTRO, C. de; RODRIGUES DA SILVA, M.R.; BORBA G.S. - 1981b - Petrologia e geoquímica do batólito e Bodoró e sotcks de Serrita, Pernambuco, In: SIMP. GEOL. NORDES TE, 10, Recife, 1981. Atas..., Recife, SBG/NNE. p. 338-401.

SIAL, A.N.; SILVA FILHO, A.F. da; GUIMARĀES, I.P. - 1983 Mineral chemistry of the late Precambrian Salgueiro batholith, State of Pernambuco, Northeast Brazil. An. Acad. Bras. Ciênc. 55(1):55-69.

SILVA FILHO, A.F. da - 1982 - Petrologia e geoqutmica do bato. lito de Salgueiro, Pernambuco. Recife, (Dissertacão de mestrado, Univ. Fed. Pernambuco), (inédito). 222 p.

SILVA FILHO, A.F. da; SIAL, A.N.; GUIMARAES, I.P. - $1982-$ $O$ batólito de Salgueiro, Pernambuco: Petrologia e Geoquímica. In: CONGR. BRAS. GEOL., 32, Salvador, 1982. A nais..., Salvador, SBG, v. 2, p. 475-489.

SILVA FILHO, M.A. da - 1985 - Projeto Cachoerinha. Recife, DNPM, Conv. DNPM/CPRM, v. 1,128 p.

SOUZA, F.S.A. - 1980 - Contribuição à geologia de parte dos municipios de Terra Nova-PE e CabrobópE, Folha Salgueiro SC.24-C-II, Area 8. Recife, (Univ. Fed. Pernambuco. Depto. Geol. Conv, DNPM/UFPE), $18 \mathrm{p}$.

SOUZA, J.O. de - 1982 - Geologia de uma área entre os munictpios de São José do Belmonte e Serra Talhada, Area 12, Recife, Univ. Fed. Pernambuco, Dept. Geol., Conv. Min. PE/UFPE, 74 p.

STRECKEISEN, A.L. - 1973 - Plutonic rocks-Classification and nomenclature recommended by the IUGS, Subcommission of the systematics of igneous rocks. Geotimes, 18:(10):26-30.

STRECKEISEN, A.L. \& LEMAITRE, R.W. - 1979 - A chemical approximation to the model QAPF classification of the igneous rocks. Neues Jahrbuch fur Mineralogie Abhandligen, 138:169-206.

TAYLOR, R.P. \& STRONG, D.F. - 1980 - The Topsails igneous *. complex: Silurian-Devonian peralkalic magmatism in western Newfoundland. Can. J. Earth Sci., 17(4):425-439.

VANDOROS, P. \& COUTINHO, J.M.V. - 1966 - Estudo geológico e geocronológico da área de São Gonçalo, Paraíba. Bol. Soc. Bras. Geol., 15(4):15-27.

WRIGHT, J.B. - 1969 - Olivine nodules in trachytes from the Jos Plateau, Nigeria. Nature, 223(5203):285-286.

MANUSCRTTO

Recebido em 10 de janeiro de 1986

Revisăo aceita em 12 de maio de 1986 